OPEN ACCESS

Edited by:

Jesse Schank,

University of Georgia, United States

Reviewed by:

Karina Possa Abrahao,

Universidade Federal de São

Paulo, Brazil

Jessica R. Barson,

Drexel University, United States

*Correspondence:

Nathan Sharfman nsharf@/suhsc.edu

Specialty section:

This article was submitted to Addictive Disorders,

a section of the journal

Frontiers in Psychiatry

Received: 25 August 2021

Accepted: 05 October 2021

Published: 04 November 2021

Citation:

Sharfman N and Gilpin NW (2021) The

Role of Melanocortin Plasticity in

Pain-Related Outcomes After Alcohol

Exposure.

Front. Psychiatry 12:764720

doi: 10.3389/fpsyt.2021.764720

\section{The Role of Melanocortin Plasticity in Pain-Related Outcomes After Alcohol Exposure}

\author{
Nathan Sharfman ${ }^{1 *}$ and Nicholas W. Gilpin ${ }^{1,2,3,4}$ \\ ${ }^{1}$ Department of Physiology, School of Medicine, Louisiana State University Health Sciences Center, New Orleans, LA, \\ United States, ${ }^{2}$ Neuroscience Center of Excellence, Louisiana State University Health Sciences Center, New Orleans, LA, \\ United States, ${ }^{3}$ Alcohol and Drug Abuse Center of Excellence, School of Medicine, Louisiana State University Health \\ Sciences Center, New Orleans, LA, United States, ${ }^{4}$ Southeast Louisiana VA Healthcare System (SLVHCS), New Orleans, LA, \\ United States
}

The global COVID-19 pandemic has shone a light on the rates and dangers of alcohol misuse in adults and adolescents in the US and globally. Alcohol exposure during adolescence causes persistent molecular, cellular, and behavioral changes that increase the risk of alcohol use disorder (AUD) into adulthood. It is established that alcohol abuse in adulthood increases the likelihood of pain hypersensitivity and the genesis of chronic pain, and humans report drinking alcohol to relieve pain symptoms. However, the longitudinal effects of alcohol exposure on pain and the underlying CNS signaling that mediates it are understudied. Specific brain regions mediate pain effects, alcohol effects, and pain-alcohol interactions, and neural signaling in those brain regions is modulated by neuropeptides. The CNS melanocortin system is sensitive to alcohol and modulates pain sensitivity, but this system is understudied in the context of pain-alcohol interactions. In this review, we focus on the role of melanocortin signaling in brain regions sensitive to alcohol and pain, in particular the amygdala. We also discuss interactions of melanocortins with other peptide systems, including the opioid system, as potential mediators of pain-alcohol interactions. Therapeutic strategies that target the melanocortin system may mitigate the negative consequences of alcohol misuse during adolescence and/or adulthood, including effects on pain-related outcomes.

Keywords: melanocortin, MC4R, pain, alcohol, opioids

\section{INTRODUCTION}

Alcohol use is estimated to be the third leading preventable cause of death in the United States (1). This estimate is likely outdated, as recent data indicates there has been an increase in alcohol-related deaths (2). Furthermore, with the recent COVID-19 pandemic, emerging data indicates escalated alcohol consumption globally that includes higher drinking in individuals with an alcohol use disorder, and also in individuals who were abstinent prior to the pandemic (3). Chronic alcohol use is associated with the development of pain disorders (4). Low to moderate alcohol drinking is associated with pain relief, and heavy alcohol use is associated with greater pain-like states (5). A large cross-sectional study from Brazil of nearly 2,300 adults revealed that excessive alcohol drinking was associated with an increased likelihood of chronic pain, whereas moderate alcohol consumption showed a somewhat protective effect against the incidence of chronic pain (6). 
Other studies have indicated similar findings, where individuals show hypersensitivity to pain-like (hyperalgesia) and innocuous (allodynia) stimuli following chronic alcohol consumption $(5,7)$.

These effects of alcohol consumption on pain sensitivity are not limited to adults, and there is evidence that similar hypersensitivities and development of pain states may occur in adolescents that use alcohol. For instance, in adolescents seeking treatment for chemical dependency, those who use alcohol are more likely to experience abdominal pains, headaches, and females are more likely to have painful reproductiverelated issues such as endometriosis, than those who do not use alcohol (8). In college drinkers, hypersensitivity is seen in binge drinkers who have recently drank alcohol within the past 2 days relative to those who drank moderately and also within the past 2 days, or abstain from alcohol (9). The use of alcohol during adolescence has long-lasting detrimental effects on behavior and neurobiology $(10,11)$. Initiation of alcohol during the adolescent period predisposes individuals to lifelong complications including increased likelihood of alcohol use disorder (AUD) and the development of psychological pathologies $(12,13)$. For instance, adolescents who drink before the age of 15 are four times more likely to develop alcohol dependence compared to those who initiate alcohol later in life (13).

Furthermore, initiation of alcohol as adolescents increases the likelihood of developing psychiatric disorders including depression, which may drive alcohol use in adulthood (14). Changes to underlying neurobiology are likely related to the behavioral outcomes in adulthood $(4,10,15)$, thus it is necessary to elucidate potential systems that (1) are sensitive to alcohol, (2) modulate alcohol-related pathologies, and (3) can be targeted by conventional methods to alleviate alcohol-specific pathologies.

Alcohol use alters responses to innocuous and noxious stimuli in adolescents $(8,9)$ and adults $(7,16,17)$ as well as neural processing of and behaviors to noxious stimuli (nociception) (18-21) and innocuous stimuli (allodynia) $(22,23)$ in preclinical models. Alterations in neuropeptide and neurotransmitter systems have been implicated in alcohol-induced alterations to behavior including corticotropin releasing factor (CRF), neuropeptide $\mathrm{Y}$, calcitonin gene related peptide, and opioids to name a few $(4,15)$. In addition, alterations to such systems occur in brain regions implicated in both the progression of AUD and processing of pain information. Cortical and subcortical regions implicated in both pain processing and alcohol use include prefrontal cortical regions, the striatum, cingulate, insula, amygdala, and periaqueductal gray $(4,15,24)$. Currently it is thought that enhancement of pro-stress neuropeptide systems underlies the transition from alcohol use to misuse $(4,24)$ and maladaptive behavioral outcomes including alcohol-induced pain sensitivity (19). However, one less examined neuropeptide system that is implicated in both alcohol-related outcomes and pain processing is the melanocortin system. We intend through this review to lay down a framework that supports the hypothesis that melanocortin system activity is associated with pain and alcohol use and enhances maladaptive outcomes such as alcoholinduced hyperalgesia. This effort is timely as negative outcomes following the pandemic will include increased substance use and side effects such as hypersensitivity, and identifying targets to mitigate both alcohol and pain can subserve a multitude of individuals.

\section{OVERVIEW OF THE MELANOCORTIN SYSTEM}

The melanocortin system was first described in the nervous system in late 1970's and 1980s (25), however it was not until the 1990's that the receptors for the melanocortin system were cloned $(26,27)$. Within the central nervous system, two predominant melanocortin receptors have been identified. The melanocortin 3 receptor (MC3R) has been primarily identified within regions of the hypothalamus, and in extra-hypothalamic regions in smaller amounts. In contrast, the melanocortin 4 receptor (MC4R) is widely distributed across the central nervous system (26-28). At the cornerstone of the melanocortin system is the prohormone pro-opiomelanocortin (POMC) that undergoes posttranslational processing by the enzymes proconvertase 1 (PC1), 2 (PC2), 3 (PC3), carboxypeptidase E, peptidyl $\alpha$ ami-dating monooxygenase, and $n$-acetyltransferase. In the anterior pituitary, corticotrophs express PC1 and PC3 that posttranslationally cleaves POMC into ACTH, $\beta$-lipotropin, and the N-terminal POMC fragment $(29,30)$. In the intermediate pituitary and hypothalamus, PC2 cleaves ACTH into ACTH 1-17 and corticotropin-like intermediate lobe peptide (CLIP). Furthermore, PC2 cleaves $\beta$-lipotropin into the opioid agonist $\beta$ endorphin and $\gamma$-lipotropin, which may be further processed into $\beta$-melanocyte stimulating hormone (31). Carboxypeptidase E, peptidyl $\alpha$-ami-dating monooxygenase, and $n$-acetyltransferase generate the mature form of $\alpha-\mathrm{MSH}$ from ACTH 1-17 (31) (see Figure 1). Importantly, these enzymes including PC1, PC2, and carboxypeptidase $\mathrm{E}$ are expressed in extra-hypothalamic brain regions, including the amygdala, hippocampus, cortex and ventral tegmental area (32-35). In addition to endogenous agonists, the melanocortin system is unique in that it also produces an endogenous antagonist agouti-related peptide (AgRP) (29). MC4R is a G-protein-coupled receptor that is coupled to the cAMP signaling pathways, where binding of $\alpha$ $\mathrm{MSH}$ increases cAMP production in a dose-dependent manner $(27,36,37)$; however, recent evidence also indicates that MC4R may signal through alternative pathways (38), which is explored in detail below.

The melanocortin system mediates a wide variety of behaviors and functions from grooming (39), sexual behaviors (27), cardiovascular tone (40), modulation of inflammation (41), to energy balance and feeding behaviors $(29,42,43)$. Early evidence also indicated that the melanocortin system interacts with the opiate system in modulating pain transmission (44-46), and subsequent data showed that antagonism of the MC4R modulates tolerance to opioid effects on nociception $(47,48)$. Since this discovery, MC4R signaling in spinal and supra-spinal regions has been implicated in modulating emotional and sensory aspects of pain (49). Furthermore, MC4R signaling modulates alcohol consumption (50) and is sensitive to the effects of chronic alcohol exposure during the adult (51) and adolescent periods (52). 


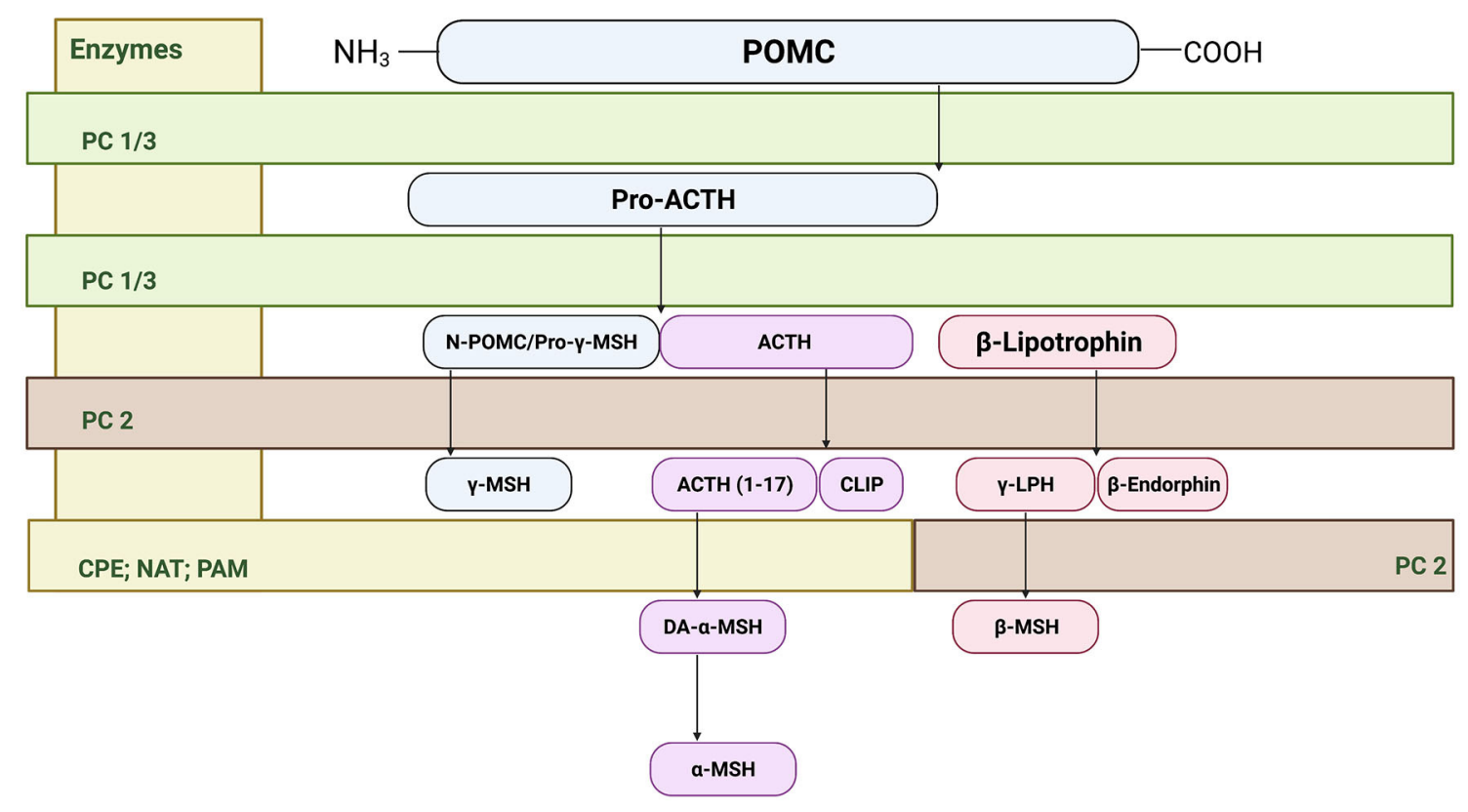

FIGURE 1 | Cleavage of precursor protein pro-opiomelanocortin (POMC). Pro-hormone convertase 1/3 (PC1/3) cleaves POMC into pro-adrenocorticotropic hormone (Pro-ACTH) and $\beta$-lipotropin. PC 1/3 further processes pro-ACTH into ACTH where proconvertase 2 (PC 2) then sequentially cleaves ACTH to ACTH (1-17) and corticotropin-like intermediate peptide (CLIP). From there, carboxypeptidase E cleaves the basic amino acid residues of ACTH (1-17) allowing amidation by peptidyl $\alpha$-ami-dating monooxygenase (PAM) to form des-acetyl- $\alpha-\mathrm{MSH}$ (DA- $\alpha-\mathrm{MSH}$ ), where then $\mathrm{n}$-acetyltransferase (NAT) acetylates DA- $\alpha$-MSH into the mature $\alpha$-MSH. PC2 also cleaves the $\mathrm{N}$-terminal portion of POMC fragement/pro- $\gamma$-melanocyte stimulating hormone (MSH) into $\gamma$-MSH. Finally, $\beta$-lipotropin is processed into the endogenous opioid $\beta$-endorphin and $\gamma$-lipotrophin.

Drug addiction including alcohol abuse can be conceptualized as a cycle of binging/intoxication, withdrawal/negative affect, and preoccupation/anticipation, whereby repeated usage of a substance places greater allostatic (maintenance of stability outside the homeostatic range) load further promoting substance use (15). Heavy use and/or binging of alcohol increases in prostress signaling in the brain, a key component underlying the neurobiology of withdrawal/negative affect stage of addiction, promoting further and escalated alcohol use (53, 54). For instance, corticotropin releasing factor (CRF) is implicated in driving stress adaptations of the hypothalamic-pitutitaryaxis and brain stress systems (55); however, there is evidence suggesting that MC4R is a part of the physiological response to stress (56-58). Stress increases melanocortin tone and broad MC4R activation elicits anxiogenic and stress-like responses (58, 59). During the withdrawal/negative affective stage of addiction, it is therefore likely that there is enhanced melanocortin tone that contributes to substance abuse. In the following sections, we will summarize the state of the science on the relationship between MC4R signaling and alcohol use, alcohol misuse and pain.

\section{MELANOCORTIN SYSTEM AND PAIN}

\section{Melanocortin and Pain Interactions}

There is a growing body of evidence implicating MC4R signaling in modulation of pain-specific behaviors in multiple models that include nerve injury, alcohol- and opioid-induced pain, and inflammation (see Table 1). Early work implicated the melanocortin system in pain-related behaviors where injections with ACTH, which is converted into fragments that agonize melanocortin receptors ( $\alpha$-MSH), produced hyperalgesic responses in rabbits (78) and rats (60). Importantly, these studies laid the foundation for a functional interaction between the opioid system and the then, undiscovered, melanocortin system. For example, $\beta$-endorphin-mediated analgesia could be abolished by pre-treatment with $\alpha$-MSH or ACTH in models of thermal nociception $(78,79)$ and electrical footshock (80). Furthermore, these effects were reliably elicited in adrenalectomized animals $(60,80)$ indicating that pain-like nocifensive (behaviors due to noxious stimuli) responses were not dependent on corticosterone. As the MC2R mediates ACTHinduced effects on hypothalamic-pituitary-axis engagement in response to a stressor (81), behavioral effects in adrenolectomized animals implicated other melanocortin receptor subtypes in the antagonism of opioid-induced analgesia. As ACTH has affinity for both MC4R and MC3R, with a slightly higher affinity for MC3R (693 vs. $86.9 \mathrm{~K}_{\mathrm{i}}$ [nmol/L], respectively) (82), studies that utilize ACTH cannot rule out the possibility of effects on MC3R. However, as previously stated, most MC3R expression is limited to the hypothalamus, septum, ventral tegmental area, and raphe nucleus $(46,83)$, nonetheless alternative studies utilizing more specific agonists and antagonists of the MC4R system were needed.

Other work indicating alternative melanocortin receptors included evidence that $\alpha$-MSH could induce hyperalgesia in naïve rats (60) prior to MC4R cloning that occurred in the 1990's (26). 
The role of the melanocortin system in regulating pain-related behaviors was originally hypothesized based on interactions between melanocortins and opioids. POMC is an opioid prohormone that incorporates both melanocortin agonists $(\alpha-\mathrm{MSH}$ and ACTH), and also opioid-receptor agonists ( $\beta$ endorphin) into a core sequence (84). Opioids in general remain the gold-standard for managing acute pain, post-surgical pain, and pain related to cancer in humans, however the continued use of opioid analgesics in patient populations has reported that nearly a quarter of patients will discontinue medication use due to adverse side effects (85). One particularly problematic side effect is the induction of hyperalgesia following chronic opioid therapy, which has been reported in both populations of individuals suffering from pain conditions such as back pain and healthy volunteers (86). Studies indicated that melanocortin agonists such as $\alpha-\mathrm{MSH}$ and ACTH antagonized the analgesic effects of morphine $(79,80,87,88)$. The melanocortin system and MC4R specifically are sensitive to effects of chronic opioid drug exposure. Administration of morphine in rats alters MC4R expression in a time- and region-specific manner, where prolonged administration leads to sustained reductions in MC4R expression in the periaqueductal gray (PAG), but a reversible decrease in the straitum (36). Furthermore, MC4R mRNA expression is decreased, but protein expression is increased in the dorsal root ganglion of morphine-treated male Wistar rats (68). Discrepancies in central and peripheral regions likely reflects region-specific neuroadaptations responding to enhanced opioid tone. For instance, a more time-specific investigation into opioid effects on MC4R expression was performed by Starowicz and colleagues. They found that acute administration of morphine decreases MC4R mRNA expression in the central nucleus of the amygdala (CeA) in male Wistar rats, whereas prolonged treatment with morphine significantly increased mRNA expression (47). The authors note however, that alterations in mRNA expression does not necessarily predict similar changes in protein expression (47). These changes highlight that $\mathrm{MC} 4 \mathrm{R}$ regulation in response to morphine likely occurs in multiple directions depending upon where in the neural axis effects are studied.

\section{Melanocortin-Opioid Interaction Effects on Pain-Like Behaviors}

Pharmacological antagonists that target both MC3R and MC4R (SHU9119, HS014) and those that have a selective affinity for MC4R (JKC-363) when given centrally to rats prevents tolerance and morphine-induced hyperalgesia (68, 70). Interestingly, subtherapeutic dosages of an MC4R antagonist, which has no effect on nociception in naïve animals, significantly attenuated tolerance to morphine (70). These results suggest an additive effect of MC4R blockade and opioid receptor agonism (68, 70), which has been further explored by bifunctional hybrid compounds. Recently, compounds that have a pharmacophore containing an enkephalin analog (Tyr-D-Ala-Gly-Phe) and MC4R antagonist derived from SHU9119 (Nle-c[Asp-His-2'DNal-Arg-Trp-Lys]) connected by various linkers have been developed. Results from these studies have indicated that these compounds have much lower effective doses as indicated by $50 \%$ effective dosages that were on the order of $1,000-10,000$ times lower than parent compounds, for producing analgesia under preclinical models of nerve injury (i.e., chronic constrictive injury to the sciatic nerve) $(74,75)$. For instance, one of the hybrids (UW3) induced analgesia 1,500 times greater relative to the parent opioid receptor compound alone and 16,000 times greater to the parent melanocortin receptor compound alone, respectively in male CD-1 mice subjected to nerve injury $(74,75)$. Furthermore, these bifunctional compounds produced long lasting effects relative to the parent opioid compound or the MC4R antagonist compound throughout the testing period (i.e., they induced a significant mechanical and thermal anti-hypersensitive effect in neuropathic injured mice relative to either parent compound alone or a mixture of the parent compounds). Finally, pretreatment with MC4R agonists abolished the anti-hypersensitive effect of these hybrid compounds in nerve injured mice (74). These results support the notion that MC4R and opioid systems interact to influence pain-like responses and furthermore, due to the molecular nature of the linkers, these data support opioid-MC4R colocalization and/or dimerization in vivo. Mu-opioid receptors and MC4R colocalization has been identified in pain-processing regions such as the PAG, where nearly $50-70 \%$ of MC4R-positive cells contain $\mu$-opioid receptors (89). It is likely therefore, that colocalization of these receptors in nodes along the pain-processing pathway mediate these effects, as recent evidence discussed below suggest a more central, rather than peripheral influence of MC4R (76) on pain processing.

\section{Melanocortin Effects in Other Pain Models}

Beyond effects of enhancing morphine's efficacy and reduction in side effects, MC4R mediates alcohols negative effects including hypersensitivity. The link between alcohol abuse and hypersensitivity has been established where individuals either going through withdrawal from alcohol or those who have imbibed chronically exhibit hypersensitivity $(4,7)$, and importantly this is also seen in young adults (9) as well as individuals who abuse alcohol during adolescence (8). In preclinical models when animals exposed to chronic alcohol undergo withdrawal, hypersensitivity emerges during this period to thermal stimuli, which can be ameliorated with intranasal, intracerebroventricular (ICV), and site-specific CeA administration of the MC4R antagonist HS014 (20, 21). Furthermore, $\mu$-opioid receptor activation in the ventrolateral PAG abolishes the pronociceptive effect of MC4R activation in the CeA; however, MC4R antagonism does not alter synaptic transmission in CeA cells projecting to the PAG (21). Thus, MC4Rrelated modulation of pain transmission may be due to MC4R effects on interneuron populations (90), reciprocal connections within the CeA (91), or projections from other regions such as the prefrontal cortex (92) that mediate pain processing.

MC4R also mediates pain-related behaviors in animal neuropathic $(61,65-67)$ and inflammatory pain models $(62,64$, 77). Neuropathic pain remains a complex condition to treat, 
TABLE 1 | Melanocortin system interactions on pain-related outcomes.

\begin{tabular}{|c|c|c|c|c|c|}
\hline References & $\begin{array}{l}\text { Pain } \\
\text { condition }\end{array}$ & Animal model & Age and/or Weight & Drugs used & Main findings \\
\hline $\begin{array}{l}\text { Sandman and Kaastin } \\
(60)\end{array}$ & None & Sprague-Dawley rats & 90 days & $\begin{array}{l}\text { ICV administration } \\
\text { - } \alpha \text {-MSH }(0.1,1,10 \mu \mathrm{g})\end{array}$ & $\begin{array}{l}\text { - ICV administration of } \alpha-\mathrm{MSH} \text { lead to hyperalgesia in } \\
\text { normal rats }\end{array}$ \\
\hline Beltramo et al. (61) & $\mathrm{CCl}$ & $\begin{array}{l}\text { Male Sprague-Dawley } \\
\text { rats }\end{array}$ & $150-175 \mathrm{~g}$ & None & $\begin{array}{l}\text { - } \mathrm{CCl} \text { Increased MC4R and precursor ligand POMC } \\
\text { gene expression in spinal cord } \\
\text { - Increased expression was generalized to spinal cord } \\
\text { and not DRG }\end{array}$ \\
\hline Bellasio et al. (62) & Formalin & Male CD1 mouse & $25-30 \mathrm{~g}$ & $\begin{array}{l}\text { Intrathecal and/or ICV } \\
\text { - MTII (5 nmol/mouse) } \\
\text { - SHU9119 (5 nmol/mouse) } \\
\text { - HS014 (5 nmol/mouse) } \\
\text { - JKC-363 (5 nmol/mouse) } \\
\text { - AgRP ( } 1.5 \mathrm{nmol} / \text { mouse) }\end{array}$ & $\begin{array}{l}\text { - MTII (I.t) decreased nociceptive thresholds in both } \\
\text { phases of the formalin pain test } \\
\text { - MC4R antagonists (SHU 9119; HS014; I.t. and ICV) } \\
\text { lead to a dose-dependent reduction in hyperalgesic } \\
\text { behaviors in second phase of formalin test }\end{array}$ \\
\hline Ercil et al. (63) & $\begin{array}{l}\text { Mouse model } \\
\text { of obesity ( } A^{y} \\
\text { mice) }\end{array}$ & $\begin{array}{l}\text { Male mice (C57BI/6 } \\
\text { background) } \\
\text { - a/a-recessive } \\
\text { - } \mathrm{A}^{\mathrm{y} / \mathrm{a}-\text { dominant }} \\
\quad \text { AgRP allele }\end{array}$ & $8-10$ weeks old & $\begin{array}{l}\text { ICV } \\
\text { - HSO14 (0.0032, 0.032, } 1 \mathrm{nmol}) \\
\text { IP } \\
\text { - Morphine }(3.2,10,32 \mathrm{mg} / \mathrm{kg})\end{array}$ & $\begin{array}{l}\text { Locomotor behavior } \\
\text { - HS014 significantly shifted the inverse U-curve } \\
\text { downward and largest dose (0.032 nmol) } \\
\text { significantly decreased motor activity at baseline } \\
\text { Antinociceptive behavior } \\
\text { - Ay mice had significantly higher baselines and were. } \\
\text { More sensitive to effects of morphine than C57BI/6 } \\
\text { mice } \\
\text { - HS014 shifted the morphine dose-response curve } \\
\text { three-fold to the left and increased baseline latencies } \\
\text { at all doses tested indicating increased potency of } \\
\text { morphine (only tested in C57BI/6 mice) }\end{array}$ \\
\hline Zvejniece et al. (64) & $\begin{array}{l}\text { Formalin test } \\
\text { Tail Flick (no } \\
\text { pain condition) }\end{array}$ & Male ICR mice & $23-25 \mathrm{~g}$ & $\begin{array}{l}\text { Peripheral admin (subcutaneous): } \\
\text { - } \alpha \text {-MSH }(0.1,1 \mu \mathrm{mol} / \mathrm{kg}) \\
\text { - HSO14 (0.1, } 1 \mu \mathrm{mol} / \mathrm{kg})\end{array}$ & $\begin{array}{l}\text { - During the formalin test } \alpha \text {-MSH showed analgesic } \\
\text { actions } \\
\text { - During tail flick only HSO14 showed analgesic } \\
\text { actions similar to indomethacin }\end{array}$ \\
\hline Vrinten et al. (65) & $\mathrm{CCl}$ & Male Wistar Rats & $200-240 \mathrm{~g}$ & $\begin{array}{l}\text { Intrathecal Admin: } \\
\text { - SHU9119 (0.14, 0.46, } 1.4 \mathrm{nmol}) \\
\text { - } \text { MTII (14.6, 29.2, 97.6, } 488 \mathrm{pmol}) \\
\text { - } \text { D-Tyr-MTII (0.29, 0.96, } 2.88 \mathrm{nmol}) \\
\text { - Nle- } \gamma \text {-MSH (3.22 nmol) } \\
\text { - } \text { Combination of MTII (14.6 pmol) and } \\
\quad \text { SHU919 (0.46 nmol) }\end{array}$ & $\begin{array}{l}\text { - SHU9119 dose-dependently increased cold and } \\
\text { mechanical thresholds in CCl, but not control rats } \\
\text { - MTII and D-Tyr-MTII dose-dependently decreased } \\
\text { cold and mechanical thresholds in CCI, but not } \\
\text { control rats }\end{array}$ \\
\hline Vrinten et al. (66) & $\mathrm{CCl}$ & Male Wistar rats & $250-300 \mathrm{~g}$ & $\begin{array}{l}\text { - SHU9119 }(0.5-1.5 \mu \mathrm{g}) \\
\text { - MT-II, }(0.5 \mu \mathrm{g}) \\
\text { - Morphine }(1-30 \mu \mathrm{g}) \\
\text { - Naloxone }(0.1-100 \mu \mathrm{g}) \\
\text { Combination } \\
\text { - Naloxone }(0.1 \mu \mathrm{g})+\text { SHU9119 }(1.5 \mu \mathrm{g}) \\
\text { - Morphine }(1-30 \mu \mathrm{g})+\text { SHU9119 }(0.5 \\
\quad \mu \mathrm{g}) \\
\text { - } \text { MTII }(1.5 \mu \mathrm{g})+\text { Morphine }(100 \mu \mathrm{g})\end{array}$ & $\begin{array}{l}\text { - SHU9119 decreased allodynia by } \mathrm{CCl} \text { and } \\
\text { pretreatment with subtherapeutic naloxone } \\
\text { decreased SHU9119-mediated effects } \\
\text { - Morphine and SHU9119 had an additive effect } \\
\text { on anti-allodynia }\end{array}$ \\
\hline
\end{tabular}


TABLE 1 | Continued

\begin{tabular}{|c|c|c|c|c|c|}
\hline References & $\begin{array}{l}\text { Pain } \\
\text { condition }\end{array}$ & Animal model & Age and/or Weight & Drugs used & Main findings \\
\hline Starowicz et al. (67) & $\mathrm{CCl}$ & Male Wistar rats & $250-300 \mathrm{~g}$ & $\begin{array}{l}\text { Intrathecal Admin } \\
\text { - SHU9119 }(0.15,0.5 \text {, and } 1.5 \mu \mathrm{g}) \\
\text { - } \text { MT-II, }(0.03,0.1 \text {, and } 0.5 \mu \mathrm{g}) \\
\text { - DAMGO }(0.1,0.25 \text {, and } 0.5 \mu \mathrm{g}) \\
\text { - Morphine }(10,20 \text {, and } 30 \mu \mathrm{g}) \\
\text { - Cyprodime }(30 \mu \mathrm{g})\end{array}$ & $\begin{array}{l}\text { - SHU9119 highest does reversed CCI effects on } \\
\text { thermal and mechanical hypersensitivity, only the } \\
\text { other doses had effects on mechanical but not } \\
\text { thermal hypersensitivity } \\
\text { - MTII affected both injured and uninjured paw } \\
\text { responses to thermal and mechanical stimuli. Dose- } \\
\text { dependently increased sensitivity to thermal and } \\
\text { mechanical stimuli } \\
\text { - Cyprodime enhanced efficacy of SHU9119 and MTII } \\
\text { - DAMGO increased mechanical thersholds that was } \\
\text { decreased by either SHU9119 or MTII }\end{array}$ \\
\hline Starowicz et al. (47) & $\begin{array}{l}\text { Morphine } \\
\text { tolerance }\end{array}$ & Male Wistar rats & $200-350 \mathrm{~g}$ & $\begin{array}{l}\text { Intra-Central Amygdala Injections } \\
\text { - SHU9119 (0.15 or } 1.5 \mu \mathrm{g}) \\
\text { - } \alpha \text {-CRF (0.5 or } 1 \mu \mathrm{g})\end{array}$ & $\begin{array}{l}\text { - Morphine acutely decreased MC4R mRNA and } \\
\text { chronically increased MC4R mRNA } \\
\text { - SHU9119 reversed morphine tolerance and } \\
\text { enhanced morphine's antihyperalgesic and allodynic } \\
\text { effect. } 0.15 \mu \mathrm{g} \text { of SHU9119 enhanced thermal but } \\
\text { not mechanical thresholds, whereas } 1.5 \mu \mathrm{g} \\
\text { enhanced both }\end{array}$ \\
\hline Starowicz et al. (48) & $\begin{array}{l}\mathrm{CCl} \\
7 \text { days } \\
\text { following they } \\
\text { were treated }\end{array}$ & Wistar Rats & $220-250 \mathrm{~g}$ & $\begin{array}{l}\text { Intrathecal administration of: } \\
\text { - SHU9119 (0.15 or } 5 \mu \mathrm{g}) \\
\text { - MT II (30 or } 100 \mathrm{ng})\end{array}$ & $\begin{array}{l}\text { - Administration of SHU9119 resulted in dose- } \\
\text { dependent increases in anti-allodynia that was } \\
\text { diminished on day } 14 \\
\text { - MT II heightened allodynic effect that was also } \\
\text { decreased on day } 14\end{array}$ \\
\hline Starowicz et al. (68) & $\begin{array}{l}\text { Morphine } \\
\text { tolerance (10 } \\
\text { mg/kg i.p.) }\end{array}$ & Male Wistar rats & $200-250$ & $\begin{array}{l}\text { Intrathecal } \\
\text { - SHU9119 (0.5 or } 1.5 \mu \mathrm{g}) \\
\text { - JKC-363 (0.7 or } 2 \mu \mathrm{g})\end{array}$ & $\begin{array}{l}\text { - SHU9119 }(1.5 \mu \mathrm{g}) \text { and JKC-363 }(0.7 \mu \mathrm{g}) \text { prevented } \\
\text { tolerance development of morphine, the lower dose } \\
\text { had no effect } \\
\text { - Single dose of drugs at both concentrations in } \\
\text { combination with morphine were able to reinstate } \\
\text { morphine efficacy on tail-flick; drugs alone had no } \\
\text { effect on tail flick assay }\end{array}$ \\
\hline Starowicz et al. (69) & $\mathrm{CCl}$ & Male Wistar rats & $220-250 \mathrm{~g}$ & $\begin{array}{l}\text { Intraplanar injection: } \\
\text { - SHU9119 (2.8 or } 11.2 \mathrm{nmol}) \\
\text { - JKC-363 (4.0, } 8.0 \mathrm{nmol})\end{array}$ & $\begin{array}{l}\text { - SHU9119 and JKC-363 reversed allodynia and } \\
\text { hyperalgesia in CCl, effects were maximal between } \\
15 \text { and } 30 \text { min. } \\
\text { - JKC-363 had longer effect than SHU9119 }\end{array}$ \\
\hline & & & & & (Continued) \\
\hline
\end{tabular}


TABLE 1 | Continued

\begin{tabular}{|c|c|c|c|c|c|}
\hline References & $\begin{array}{l}\text { Pain } \\
\text { condition }\end{array}$ & Animal model & Age and/or Weight & Drugs used & Main findings \\
\hline Kalange et al. (70) & $\begin{array}{l}\text { Morphine } \\
\text { withdrawal } \\
\text { hyperalgesia }\end{array}$ & $\begin{array}{l}\text { Male Sprague-Dawley } \\
\text { rats }\end{array}$ & $220-260 \mathrm{~g}$ & $\begin{array}{l}\text { Acute treatments: } \\
\text { ICV administration } \\
\text { - Morphine (2-20 } \mu \mathrm{g} / \mathrm{rat}) \\
\text { - HSO14 (0.008- } 0.08 \mathrm{ng} / \mathrm{rat}) \\
\text { - NDP-MSH (0.04-0.12 ng/rat) } \\
\text { Chronic treatment } \\
\text { ICV administration } \\
\text { - HSO14 (0.008ng/rat) } \\
\text { Osmotic Minipump } \\
\text { - Morphine }(20 \mathrm{ng} / \mu \mathrm{l} / \mathrm{h})\end{array}$ & 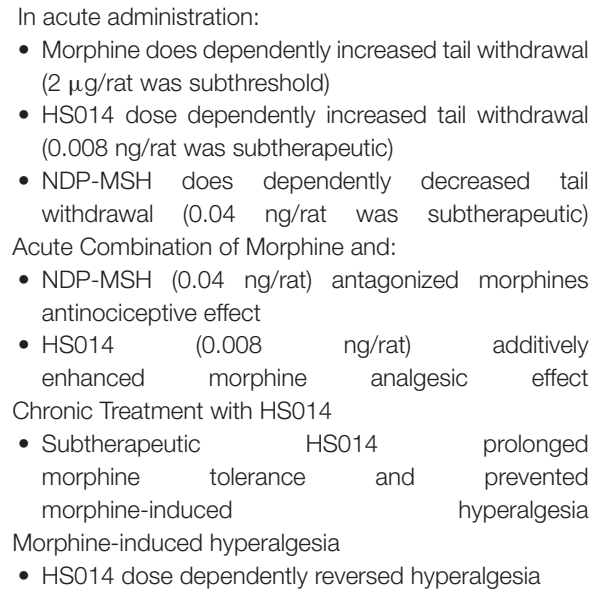 \\
\hline Chu et al. (71) & $\mathrm{CCl}$ & Male Wistar rats & $280-320 \mathrm{~g}$ & $\begin{array}{l}\text { Intrathecal admin for } 7 \text { days } \\
\text { - HSO14 (5 } \mu \mathrm{g} / \text { day }) \\
\text { - SB203580 (10 mg/day) }\end{array}$ & $\begin{array}{l}\text { - Administration of HSO14 resulted in anti-allodynia that } \\
\text { was preserved after cessation of drug } \\
\text { - Following CCI surgery both the group that received } \\
\text { HSO14 and the group that received SB203580 } \\
\text { showed reduced signs of thermal and mechanical } \\
\text { hypersensitivity relative to group treated with saline }\end{array}$ \\
\hline Chu et al. (72) & $\mathrm{CCl}$ & Male Wistar Rats & $200-250 \mathrm{~g}$ & $\begin{array}{l}\text { PAG injections } \\
\text { - HS014 (dose } 1 ; 0.1 \mu \mathrm{mol} / 0.5 \mu \mathrm{L} \text {, dose } \\
\text { 2; } 1 \mu \mathrm{mol} / 0.5 \mu \mathrm{L} \text { ) }\end{array}$ & $\begin{array}{l}\text { - HS014 reduced thermal and mechanical } \\
\text { hypersensitivity from CCl }\end{array}$ \\
\hline $\begin{array}{l}\text { Roltsch-Hellard et al. } \\
\text { (20) }\end{array}$ & $\begin{array}{l}\text { Alcohol- } \\
\text { induced } \\
\text { hyperalgesia }\end{array}$ & Male Wistar Rats & $250 \mathrm{~g}$ & $\begin{array}{l}\text { ICV administration } \\
\text { - AgRP }(0.05,0.1 \text {, and } 0.2 \mu \mathrm{g}) \\
\text { Intranasal administration } \\
\text { - HS014 (0 or } 50 \mu \mathrm{g} / 10 \mu \mathrm{L})\end{array}$ & $\begin{array}{l}\text { - AgRP increased thermal thresholds in alcohol } \\
\text { dependent animals, but had no effect on } \\
\text { non-dependent nor alcohol naïve animals } \\
\text { - ICV and intranasal administration of HSO14 reverses } \\
\text { alcohol-dependent hyperalgesia }\end{array}$ \\
\hline Avegno et al. (21) & $\begin{array}{l}\text { Alcohol- } \\
\text { induced } \\
\text { hyperalgesia }\end{array}$ & Male Wistar rats & $300 \mathrm{~g}$ & $\begin{array}{l}\text { Intra-CeA injection } \\
\text { - HSO14 }(0.05,0.1 \text {, or } 0.2 \mathrm{ng}) \\
\text { - } \alpha-\mathrm{MSH}(0.3 \text { or } 1 \mu \mathrm{g}) \\
\text { Intra-PAG injection } \\
\text { - DAMGO }(0.1 \text { or } 0.5 \mu \mathrm{g})\end{array}$ & $\begin{array}{l}\text { - HSO14 decreased in alcohol-dependent rats whereas } \\
\alpha \text {-MSH increased in alcohol-naïv rats hindpaw } \\
\text { withdrawal latency } \\
\text { - Pre-treatment with DAMGO blocked } \alpha-M S H \text { (CeA; } \\
0.3 \mu \mathrm{g} \text { ) pro-nociceptive effects }\end{array}$ \\
\hline Zhao et al. (73) & $\mathrm{CCl}$ & $\begin{array}{l}\text { Male Sprague-Dawley } \\
\text { rats }\end{array}$ & $200-250 \mathrm{~g}$ & 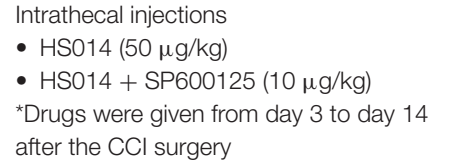 & $\begin{array}{l}\text { - HS014 alone or in combination with with JNK } \\
\text { inhibitor SP600125 alleviated thermal and } \\
\text { mechanical hypersensitivity relative to CCI }\end{array}$ \\
\hline
\end{tabular}


TABLE 1 | Continued

\begin{tabular}{|c|c|c|c|c|c|}
\hline References & $\begin{array}{l}\text { Pain } \\
\text { condition }\end{array}$ & Animal model & Age and/or Weight & Drugs used & Main findings \\
\hline $\begin{array}{l}\text { Starnowska-Sokół et al. } \\
\text { (74) }\end{array}$ & $\mathrm{CCl}$ & $\begin{array}{l}\text { Male Albino Swiss } \\
\text { CD-1 IGS mice }\end{array}$ & $30-35 \mathrm{~g}$ & $\begin{array}{l}\text { Intrathecal injections } \\
\text { - Novel opioid agonist, MC4R antagonist } \\
\text { hybrids (UW1 [parent opioid } \\
\text { compound], UW3, UW5, UW9, UW10) } \\
\text { - SHU9119 (0.09-23.27 [naïve mice]; } \\
\text { - } 0.9-9.3 \text { [CCI] nmol) } \\
\text { - Naltrindole Hydrochloride (Delta-opioid } \\
\text { receptor antagonist) } \\
\text { - Naloxone (opioid receptor antagonist) } \\
\text { - THIQ (2.5 nmol; MC4R agonist) } \\
\text { - MTII (1.5 nmol; MC agonist) }\end{array}$ & $\begin{array}{l}\text { In Naïve Mice: } \\
\text { - SHU9119 had no effect on tail-flick } \\
\text { In CCI Mice: } \\
\text { - Both UW1 (parent opioid compound) and SHU9119 } \\
\text { alleviated CCI mechanical hypersensitivity, but effects } \\
\text { diminished after } 90 \text { min } \\
\text { - Novel Hybrid compounds had lower ED Eo's (UW3 = } \\
\text { 0.0002; UW10 0.003; vs. parent opioid compound } \\
\text { UW1 = 0.16 or MC4R antagonist SHU9119=3.33) } \\
\text { and had longer antinociceptive effect } \\
\text { - Pretreatment with opioid antagonists (Naloxone or } \\
\text { Naltrindole) or Melanocortin agonists (MTII or THIQ) } \\
\text { significantly reduced and/or completely abolished the } \\
\text { anti-nociceptive effects of hybrid compounds UW3 } \\
\text { and UW5 } \\
\text { - Hybrid compounds had a significant antinociceptive } \\
\text { effect compared to mixtures of UW1 and SHU9119 }\end{array}$ \\
\hline Piotrowska et al. (75) & $\mathrm{CCl}$ & Male Wistar rats & $200-260 \mathrm{~g}$ & $\begin{array}{l}\text { Intrathecal Admin } \\
\text { - } \alpha \text {-MSH }(0.1,10,50 \mu \mathrm{g} / 5 \mu \mathrm{L}) \\
\text { - ACTH }(1,10,50 \mu \mathrm{g} / 5 \mu \mathrm{L}) \\
\text { - CLIP }(10 \text { and } 50 \mu \mathrm{g} / 5 \mu \mathrm{L} \\
\text { - SHU9119 }(1 \mu \mathrm{g} / 5 \mu \mathrm{L}) \\
\text { *UW1 and UW5 - novel bifunctional } \\
\text { compounds with enkephalin analog and } \\
\text { MC4R antagonist (0.001, 0.01, and } 0.1 \\
\mu \mathrm{g} / 5 \mu \mathrm{L})\end{array}$ & $\begin{array}{l}\text { - } \mathrm{ACTH}, \alpha-\mathrm{MSH} \text {, and CLIP increased mechanical and } \\
\text { thermal hypersensitivity after CCl. } \\
\text { - } \alpha \text {-MSH dose-dependently increased mechanical and } \\
\text { thermal hypersensitivity } \\
\text { - } \gamma \text {-MSH }(1 \mu \mathrm{g} / 5 \mu \mathrm{L}) \text { decreased hypersensitivity, } \\
\text { whereas }(10 \mu \mathrm{g} / 5 \mu \mathrm{L}) \text { increased hypersensitivity } \\
\text { - SHU9119 produced mechanical and thermal } \\
\text { antinociceptive effects in CCl animals } \\
\text { - UW3 and UW5 showed analgesic effects of all doses } \\
\text { tested and lasted } 2 \mathrm{~h} \\
\text { - In the management of neuropathy, UW3 and UW5 } \\
\text { (0.1 } 1 \mu \mathrm{g} / 0.5 \mu \mathrm{L} \text { ) exhibited longer analgesic efficacy } \\
\text { relative to morphine in CCl animals treated for } 9 \\
\text { days (starting on after day } 7 \text { of CCI) }\end{array}$ \\
\hline Robinson et al. (76) & $\begin{array}{l}\text { Red-haired } \\
\text { male mice }\end{array}$ & $\mathrm{MC} \mathrm{R}^{\mathrm{e} / \mathrm{e}}$ male mice & 8 weeks & $\begin{array}{l}\text { PAG administration } \\
\text { - Melanotan II }(150 \mathrm{ng} / 2 \mu \mathrm{L}) \\
\text { - Naloxone }(3 \mu \mathrm{g} / 2 \mu \mathrm{L}) \\
\text { - Naloxonazine }(1.5 \mu \mathrm{g} / 2 \mu \mathrm{L})\end{array}$ & $\begin{array}{l}\text { PAG administration resulted in: } \\
\text { - Decreased thermal nociceptive thresholds with } \\
\text { MC4R agonism } \\
\text { - Blockade of opioid receptors reduced } \\
\text { nociceptive threshold }\end{array}$ \\
\hline Klawonn et al. (77) & $\begin{array}{l}\text { MC4R } \\
\text { knockout } \\
\text { mice }\end{array}$ & Male MC4R-STOP-flox & 6-20 weeks old & $\begin{array}{l}\text { Conditioning paradigm: } \\
\text { - LPS (lipolysaccharide; } 10 \mu \mathrm{g} / \mathrm{kg} \text { ) } \\
\text { - HS014 (50 } \mathrm{g} / 5 \mu \mathrm{L}\end{array}$ & $\begin{array}{l}\text { Conditioning results; } \\
\text { - LPS injected mice displayed aversion to injection, } \\
\text { MC4R lacking mice displayed preference to LPS } \\
\text { and other aversive stimuli (lithium chloride, k-opioid } \\
\text { receptor agonist) } \\
\text { - WT mice treated with intranasal HSO14 also } \\
\text { displayed preference to LPS, greater time spent in } \\
\text { hot plate, and antinociceptive effects }\end{array}$ \\
\hline
\end{tabular}


as pain relief is poorly managed in patients with less than half achieving effective pain relief (93). Preclinical models of neuropathic pain suggest a dysregulation of the melanocortin system in the dorsal root ganglion (DRG) and dorsal horn of the spinal cord. MC4R gene and protein expression has shown divergent changes following neuropathy, reportedly with protein expression increased (69) and gene expression either being decreased (48) or unchanged (61) in the DRG. This may be an adaptive mechanism wherein increased expression results in downregulation of MC4R at the transcript level. However, local intra-plantar injection of MC4R antagonists JKC-363 and SHU9119 ameliorate thermal and mechanical hypersensitivity to neuropathic pain, indicating that the increase in expression at the protein level promotes pain (69). The results of neuropathic pain on MC4R levels in other regions of the CNS are more consistent, with groups showing increases in MC4R in spinal regions, including the dorsal horn of the spinal cord, specifically in localized to layers I and II $(65,69$, 94, 95), and supraspinal regions that mediate pain transmission including the PAG (72). Interestingly, MC4R antagonism not only reverses neuropathic-like pain states in preclinical models $(48,65,69,74,75,94)$, but these effects may be in part mediated via mitogen activated protein kinase (MAPK) pathways. In both DRG and the spinal cord, MC4R blockade decreased both MC4R cell numbers and p38 MAPK expression $(71,95)$. In addition, HSO14 also significantly decreases JNK pathway activation and pro-inflammatory markers that are postulated to heighten neuropathic pain (73). Collectively, these data suggest that MC4R is, and remains, a highly important therapeutic target as MC4R antagonism attenuates pain-like behavior in multiple animal models. It is interesting to consider that antagonism of this receptor leads to anti-hyperalgesia, where discussed in the next section, agonism of the receptor alters the response to alcohol.

\section{MELANOCORTIN SYSTEM AND ALCOHOL Effects of Alcohol on the Melanocortin System}

Considerable work has been done on investigating the effects of alcohol on melanocortin receptors, its ligands, precursor products, and components of the melanocortin system. In response to chronic ethanol, POMC in hypothalamic sites has been reported to be increased (96), decreased (97-100), or not changed (101), although discrepancies in previous reports are likely due to methodological differences in administration of ethanol. For instance, De Waele and Gianoulakis (96) reported increases in $\beta$-endorphin in the arcuate nucleus and septum, however this was following 21 days of access to $10 \%$ volume/volume ethanol, although that study did not state when following the treatment animals were sacrificed for tissue processing (i.e., during withdrawal when alcohol levels in the blood are negligible, or if there was still alcohol in the system of the animals). Later studies indicated a time-dependent effect of alcohol on POMC precursors where, during alcohol treatment, animals display lower levels of POMC mRNA but following treatment there were increases in POMC mRNA $(97,98)$. Thus, the effect of alcohol and alcohol withdrawal likely affect POMC expression as has been reported with other systems affected by alcohol (24).

The endogenous agonist of MC4R, $\alpha-\mathrm{MSH}$, has been reported to be both decreased $(102,103)$ and increased $(104,105)$ following chronic ethanol exposure in rats. On the other hand, acute ethanol exposure produces decreases in $\alpha$-MSH $(102,105$, 106), POMC, and enzymes that cleave POMC to produce $\alpha$ MSH including PC1 and PC3 (107). In acute alcohol exposure models, decreases in $\alpha$-MSH fibers have been reported in the extended amygdala (bed nucleus of the stria terminalis; BNST), CeA, dorsomedial hypothalamus, paraventricular nucleus of the hypothalamus (102), and both fibers and cell bodies of the arcuate nucleus, a major hub that synthesizes the $\alpha$ MSH precursor POMC $(29,107)$. Interestingly, there is also a decrease in the PC1 and PC3 enzymes within the arcuate nucleus as well (107). Data however is less clear following chronic ethanol exposure. Rainero et al. (103) as well as Navarro et al. (102) both describe decreases of either $\alpha-\mathrm{MSH}$ or the precursor POMC within the arcuate nucleus, decreases of $\alpha$ MSH in the BNST, CeA, lateral hypothalamus, pituitary, and substantia nigra after chronic alcohol exposure. This is contrasted to data from Kokare et al. (105) that showed increases in $\alpha$ MSH in the CeA, and in hypothalamic divisions including the paraventricular nucleus, arcuate nucleus, and dorsomedial nucleus. Unfortunately, these data are difficult to reconcile as all studies used male Sprague-Dawley rats, liquid ethanol diets, and similar exposure timeframes; it is likely that alcohol effects are brain region- and strain-specific. For instance, 129/SvJ mice that exhibit decreased preference and consumption of alcohol also exhibit higher $\alpha$-MSH fiber quantity in the medial amygdala, and conversely, lower fiber quantity in the lateral and dorsomedial hypothalamus, whereas C57BL/6 mice that exhibited higher preference for alcohol had an inverse expression pattern, with greater $\alpha$-MSH fiber quantity in hypothalamic regions, but decreased fiber quantity in the medial amygdala (102).

Data from Kokare and colleagues shed light on what may occur during withdrawal: they reported an increase in $\alpha$-MSH fiber immunoreactivity in animals treated with chronic ethanol exposure in regions including the arcuate nucleus and CeA (105). Supporting data has been seen with POMC mRNA expression that is potentiated weeks after chronic ethanol treatment has ended (98). Furthermore, MC4R expression is decreased, but $\alpha$-MSH expression trends toward an increase within the CeA during withdrawal (21). The data thus far indicates that the melanocortin system responds both to acute and chronic alcohol challenges, however future studies are necessary to clarify acute and chronic ethanol effects on MC4R and its ligands over time.

\section{MC4R Effects on Alcohol Intake}

MC4R agonism reduces ethanol intake [see (106) and Table 2]. This contrasts evidence presented above where MC4R antagonism reduces pain-like behaviors in multiple preclinical models. Initial evidence for the effects of MC4R signaling on alcohol intake was established by Ploj and collegues where in alko-accepting rats (AA) bred for high ethanol preference, MTII, 
a non-selective MC3R and MC4R agonist, reduced ethanol consumption when given via the ICV route (108). Importantly, MC4R antagonism with HS014 had no effect on alcohol intake indicating that pharmacological agonism, but not antagonism altered ethanol intake (108). This has been consistently affirmed in both rat and mouse models of alcohol drinking across different paradigms (Table 2). Furthermore, broad and sitespecific administration of MC4R agonism has delineated specific neural pathways involved in modulation of both ethanol intake and characteristics of ethanol including palatability.

The role of MC4R in regulating ethanol drinking was confirmed by a study from Navarro and colleagues where they showed that MTII when given ICV reduced ethanol drinking in $\mathrm{MC}_{4} \mathrm{R}^{+/+}$mice, but not MC4R $\mathrm{R}^{-/-}$mice (113). Furthermore, they saw that this effect was not only limited to ethanol intake but also other caloric sources including food and sucrose and non-caloric reinforcers such as saccharin (113). Multiple studies have confirmed that agonism of MC4Rs blunts ethanol intake in diverse alcohol intake paradigms including voluntary consumption (108-111, 114, 115), and binge-like drinking (112, 117-121) in both mice and rats. Studies have indicated that the reduction in ethanol intake is associated with decreases in caloric intake as food was decreased following agonism of MC4R $(109,114,119)$. Although it is well-known that MC4Rs mediate food intake (29), and that agonism of MC4R decreases feeding $(122,123)$ the effects on ethanol intake are likely dependent on non-homeostatic mechanisms of caloric regulation. For example, York and colleagues described a decrease in ethanol intake in alcohol preferring rats when MTII was given into the CeA and basolateral amygdala (BLA) regions that lasted longer than observed decreases in food intake (114). Furthermore, when rats were calorically controlled (i.e., animals receiving drug had their calorie intake matched to control animals to investigate changes in alcohol consumption), effects of MC4R agonism resulted in prolonged depression of ethanol intake and preference (114). These data indicate that, at least in certain nodes of the neuraxis, MC4R modulation of ethanol intake depends on homeostatic and non-homeostatic mechanisms. In support of non-homeostatic related-mechanisms of MC4R modulation on ethanol intake, targeting MC4Rs located in the arcuate nucleus, a key node in the regulation of homeostatic feeding control $(26,29)$, agonism had no effect on ethanol intake in alcohol-preferring rats (111).

MC4R antagonism has fewer clear effects on ethanol intake in preclinical models. It has been reported that MC4R antagonism has no effect $(108,109)$, a decreased effect (114), and an increased effect (110) on ethanol intake. Discrepancies in these findings may be due to (1) location of pharmacological agents administered into the CNS, (2) temporal effects of pharmacological agents, (3) duration of ethanol exposures, (4) pharmacological agents that were used, and (5) species. Navarro and collegues found that a low $(0.05 \mu \mathrm{g})$ but not high $(0.1$ $\mu \mathrm{g})$ dose of AgRP increased ethanol intake in the two bottle choice model in C57BL/6J mice (110). This is in contrast to data from Ploj and colleagues that showed no effect of the selective antagonist HS014 on ethanol intake in female alcoholpreferring rats (108), and is also in disagreement from an earlier study by the same group showing that higher doses of AgRP
(5.0 $\mu \mathrm{g}$ ) had no effect on ethanol intake (109). It may be that lower doses of AgRP effectively increase ethanol drinking, whereas higher doses have no effect. In line with the literature, pretreatment with either AgRP (110) or HS014 (121) effectively blunts MC4R agonist-induced decreases in ethanol drinking. A decrease in ethanol drinking following administration of SHU9119, an MC4R antagonist, has also been reported in male rats that prefer alcohol (114). However, the decrease in ethanol drinking was concluded to be likely due to secondary effects on water consumption, which increased in both the amount and preference, prior to the decrease in ethanol intake (114). Finally, this decrease in ethanol intake was replicated with intraamygdalar injections (114), thus the discrepancies may be due to site-specific modulation of MC4Rs. For instance, administration of MTII into the NAc or VTA reduces the amount of voluntary ethanol intake in rats (115), whereas administration into the lateral hypothalamus or the third ventricle (111) has no effect on ethanol intake. In other addiction-related brain regions, such as the nucleus accumbens shell, MC4R agonism results in a decrease in the hedonic effects and an increase in the aversive effects of ethanol (115). Importantly, the effects of MC modulation are limited to ethanol intake, and do not extend to consummatory behaviors. Injection of MTII into the posterior VTA, a region important for alcohol reinforcement, had no effect on operant conditioning responses alone (i.e., lever presses in the absence of a reinforcer were not affected) (124). Taken together, the decrease in ethanol intake seen following MC4R agonism is likely the result of a combination of non-hedonic factors that include increases in ethanol aversion and homeostatic behaviors including a decrease in the drive to consume caloric compounds.

\section{Opioids and Melanocortin Interactions Effects on Alcohol Intake}

MC4R agonism reduces the hedonic value of alcohol (110) while increasing the aversive effects of ethanol (119). It is well-known that opioids also influence the intake and hedonic nature of ethanol. In general, opioid agonism increases ethanol intake whereas antagonism decreases ethanol intake [for a review see (125)]. Blockade of opioid receptors not only modulates ethanol intake but also the hedonic effects of alcohol, similar to MC4R. Opioid receptor antagonism with naltrexone increases aversive responses to ethanol and shifts the palatability of ethanol in rats at low (126) and high doses (127). Naltrexone is FDA approved for alcohol addiction, whereas bupropion is a dopamine and norepinephrine reuptake inhibitor that is approved for depression and smoking cessation (128). To our knowledge, bupropion does not activate MC4R directly however there is evidence supporting an indirect activation of MC4R via modulation of POMC and/or $\alpha$-MSH expression (106, 129). In animals treated with a high-fructose corn syrup diet, decreases in hypothalamic POMC expression were abrogated by bupropion and furthermore, bupropion also increases expression of BDNF in the hippocampus in rats (129). Importantly, $\mathrm{BDNF}$ can bind to the promotor region of POMC, thereby enhancing expression, and thus driving melanocortin tone (130). Electrophysiological data suggests that bupropion enhances 
TABLE 2 | Melanocortin system interactions on alcohol drinking.

\begin{tabular}{|c|c|c|c|c|c|}
\hline References & Animal model & Age and/or Weight & Drinking paradigm & Drugs & Outcomes on drinking behavior \\
\hline $\begin{array}{l}\text { Ploj et al. } \\
\text { (108) }\end{array}$ & $\begin{array}{l}\text { Female AA rats bred for } \\
\text { alcohol consumption }\end{array}$ & $\begin{array}{l}116-177 \mathrm{~g} \text { at beginning } \\
\text { and } 141-213 \mathrm{~g} \text { at the } \\
\text { end }\end{array}$ & $\begin{array}{l}\text { Rats were given two bottle choice } \\
\text { after } 7 \text { days of only ethanol drinking } \\
(10 \% \mathrm{v} / \mathrm{v}) \text { throughout the } \\
\text { experiment }\end{array}$ & $\begin{array}{l}\text { ICV administration } \\
\text { - HSO14 (1nmol/rat) } \\
\text { - MTII (1nmol/rat) }\end{array}$ & $\begin{array}{l}\text { - MTII significantly reduced consumption } \\
\text { and preference for ethanol, which } \\
\text { returned to baseline values } \\
\text { - HSO14 had no effect on drinking }\end{array}$ \\
\hline $\begin{array}{l}\text { Navarro } \\
\text { et al. (109) }\end{array}$ & $\begin{array}{l}\text { C57BL/6NTac (mouse } \\
\text { line bred to prefer } \\
\text { alcohol) }\end{array}$ & $25-30 \mathrm{~g}$ & $\begin{array}{l}\text { Two bottle choice ( } 8 \% \mathrm{w} / \mathrm{v} \text { EtOH) } \\
\text { for } 2 \text { weeks then } 8 \mathrm{~h} \text { sessions of } \\
\text { ethanol, food and water intake }\end{array}$ & $\begin{array}{l}\text { ICV administration } \\
\text { - AgRP } 83-132(5.0 \mu \mathrm{g}) \\
\text { - MTII }(1.0 \mu \mathrm{g}) \\
\text { Intraperitoneal injection } \\
\text { - MTII (100 or } 150 \mu \mathrm{g})\end{array}$ & $\begin{array}{l}\text { Central Administration: } \\
\text { - MTII significantly decreased EtOH and } \\
\text { food intake. Effect was blocked by } \\
\text { pretreatment with AgRP Peripheral } \\
\text { Administration } \\
\text { - } 150 \mu \mathrm{g} \text { MTII decreased EtOH and food } \\
\text { consumption, } 100 \mu \mathrm{g} \text { MTII decreased } \\
\text { food consumption }\end{array}$ \\
\hline $\begin{array}{l}\text { Navarro } \\
\text { et al. (110) }\end{array}$ & $\begin{array}{l}\text { MC3R deficient } \\
\left(\mathrm{Mc} 3 \mathrm{r}^{-/-}\right) \\
\text {MC3R mice }\left({\left.\mathrm{Mc} 3 \mathrm{r}^{+/+}\right)} \text {on a }\right. \\
\text { C57BL/6J background }\end{array}$ & 8-12 week mice & Two bottle choice (20\% v/v EtOH) & $\begin{array}{l}\text { ICV administration } \\
\text { - AgRP } 83-132(0.05 \text { or } 0.1 \mu \mathrm{g}) \\
\text { - MTII }(1.0 \mu \mathrm{g}) \\
\text { - Selective MC4R agonist: cyclo( }\left(\mathrm{NH}-\mathrm{CH}_{2}-\right. \\
\mathrm{CH}_{2}-\mathrm{CO}-\text { His-d-Phe-Arg-Trp-Glu)- } \mathrm{NH}_{2} \\
\text { ( } 1.0 \text { or } 3.0 \mu \mathrm{g}) \\
\text { Intraperitoneal injection } \\
\text { - MTII (10 mg/ka) }\end{array}$ & $\begin{array}{l}\text { Central Administration } \\
\text { - MTII reduced Ethanol drinking and } \\
\text { preference in both } \mathrm{Mc} \mathrm{r}^{-/-} \text {and } \mathrm{Mc} 3 \mathrm{r}^{+/+} \\
\text {mice } \\
\text { - Selective MC4R agonist dose- } \\
\text { dependently decreased ethanol and } \\
\text { food intake } \\
\text { - AgRP increased ethanol intake } \\
\text { only at the } 0.05 \mathrm{\mu g} \text { dose } \\
\text { Peripheral Administration } \\
\text { - MTII reduced Ethanol drinking and } \\
\text { preference in both } \mathrm{Mc} 3 \mathrm{r}^{-/-} \text {and } \mathrm{Mc} 3 \mathrm{r}^{+/+} \\
\text {mice } \\
\text { - MTIl also decreased food intake in } \\
\text { both strains }\end{array}$ \\
\hline $\begin{array}{l}\text { Polidori } \\
\text { et al. (111) }\end{array}$ & Marchig-Sardinian & $360-380 \mathrm{~g}$ & $\begin{array}{l}2 \text { and } 24 \mathrm{~h} \text { access } \\
\text { - } 10 \% \mathrm{w} / \mathrm{v}\end{array}$ & $\begin{array}{l}\text { ICV (LV and third ventricle; 3V) } \\
\text { Administration } \\
\text { - } \text { MT (0.1 [only dose used for 3V]and } 1 \\
\text { nmol) } \\
\text { - SHU9119 (0.5 nmol) } \\
\text { - AgRP (1 nmol) }\end{array}$ & $\begin{array}{l}\text { Central Administration } \\
\text { - MTIl reduced Ethanol drinking only at a } \\
\text { dose of } 1 \mathrm{nmol} \text { in the LV as a single dose } \\
\text { - Repeated administration of MTII over } 5 \\
\text { days in animals with } 24 \mathrm{~h} \text { access to EtOH } \\
\text { during the first } 8 \text { and } 24 \mathrm{~h} \text {, but not the first } \\
2 \mathrm{~h} \\
\text { - Antagonism had no effect on } \\
\text { alcohol intake }\end{array}$ \\
\hline $\begin{array}{l}\text { Navarro } \\
\text { et al. (112) }\end{array}$ & $\begin{array}{l}\text { AgRP deficient } \\
\left(\mathrm{AgRP}^{-/-}\right) \text {mice } \\
\text { Wildtype mice } \\
\left(\mathrm{AgRP}^{+/+}\right) \text {on } \\
\text { C57BL/6J background }\end{array}$ & $\begin{array}{l}8 \text { weeks } \\
\text { Male and Female for } \\
\text { Two-bottle choice and } \\
\text { Bing-like ethanol } \\
\text { drinking }\end{array}$ & $\begin{array}{l}\text { - Operant conditioning (8\% v/v } \\
\text { EtOH; } 1-3 \% \text { sucrose, 0.01-0.1\% } \\
\text { w/v saccharin) } \\
\text { - Two-bottle choice (8\% v/v EtOH) } \\
\text { - } \text { Binge-like EtOH } \\
\text { - }(20 \% \text { EtOH) } \\
\text { - EtOH-induced sedation ( } 4.0 \mathrm{~g} / \mathrm{kg} \text {; } \\
\\
19 \% \mathrm{w} / \mathrm{v} \text { intraperitoneal injection) }\end{array}$ & None & $\begin{array}{l}\text { - AgRP }{ }^{-/-} \text {mice exhibited significantly less } \\
\text { ethanol lever pressing and consumption } \\
\text { o Similar effect in binge condition; } \\
\text { AgRP }^{-/} \text {mice exhibited reduced } \\
\text { ethanol drinking and lower blood } \\
\text { alcohol levels } \\
\text { - Both male and female AgRP- mice } \\
\text { exhibited less preference for ethanol in } \\
\text { the two-bottle choice } \\
\text { - AgRP likely positively modulates } \\
\text { ethanol drinking }\end{array}$ \\
\hline
\end{tabular}


TABLE 2 | Continued

\begin{tabular}{|c|c|c|c|c|}
\hline References & Animal model & Age and/or Weight & Drinking paradigm & Drugs \\
\hline $\begin{array}{l}\text { Navarro } \\
\text { et al. (113) }\end{array}$ & 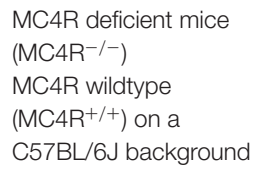 & 6 week & $\begin{array}{l}\text { - Two-bottle choice } \\
\text { - (3-20\% v/v EtOH) }\end{array}$ & $\begin{array}{l}\text { ICV administration } \\
\text { - MTII (0.5 or } 1.0 \mu \mathrm{g}) \\
\text { Intraperitoneal injection } \\
\text { - MTII }(5 \mathrm{mg} / \mathrm{kg})\end{array}$ \\
\hline $\begin{array}{l}\text { York et al. } \\
(114)\end{array}$ & $\begin{array}{l}\text { Male Alcohol preferring } \\
\text { (P) and non-preferring } \\
\text { (NP) rats }\end{array}$ & $\begin{array}{l}6 \text { weeks } \\
\text { (first cohort; P: 299 g, } \\
\text { NP: 269; second } \\
\text { cohort; P: 284, NP: } \\
\text { 310) }\end{array}$ & $\begin{array}{l}\text { - Two bottle choice } \\
\text { - }(7.5 \% \mathrm{w} / \mathrm{v})\end{array}$ & $\begin{array}{l}\text { Intra-CeA injections } \\
\text { - MTII (0.5 nmol) } \\
\text { - SHU9119 (1 nmol) } \\
\text { - HS104 (1 nmol) }\end{array}$ \\
\hline $\begin{array}{l}\text { Lerma- } \\
\text { Cabrera } \\
\text { et al. (115) }\end{array}$ & $\begin{array}{l}\text { Male Sprague Dawley } \\
\text { rats }\end{array}$ & $280-300 \mathrm{~g}$ & $\begin{array}{l}\text { Two-bottle choice }(6 \% \mathrm{w} / \mathrm{v}) \text { for } \\
\text { a month }\end{array}$ & $\begin{array}{l}\text { VTA, NAc, or LH injections } \\
\text { - HSO14 }(0.02 \text { or } 0.05 \mu \mathrm{g}) \\
\text { - cyclo( }\left(\mathrm{NH}^{-} \mathrm{CH}_{2}-\mathrm{CH}_{2}-\mathrm{CO}-\text { His-d-Phe-Arg- }\right. \\
\text { Trp-Glu)- } \mathrm{NH}_{2}(0.75 \text {, } \\
\quad 1.5 \mu \mathrm{g})\end{array}$ \\
\hline $\begin{array}{l}\text { Lerma- } \\
\text { Cabrera } \\
\text { et al. (116) }\end{array}$ & $\begin{array}{l}\text { Male Sprague Dawley } \\
\text { rats }\end{array}$ & $280-300 \mathrm{~g}$ & $\begin{array}{l}\text { Two-bottle choice }(6 \% \mathrm{w} / \mathrm{v}) \text { for a } \\
\text { month and then taste } \\
\text { reactivity testing }\end{array}$ & $\begin{array}{l}\mathrm{NAc} \text { or } \mathrm{LH} \text { injections } \\
\text { - } \mathrm{cyclo}\left(\mathrm{NH}-\mathrm{CH}_{2}-\mathrm{CH}_{2} \text {-CO-His-d-Phe-Arg- }\right. \\
\text { Trp-Glu)- } \mathrm{NH}_{2}(0.75 \\
1.5 \mu \mathrm{g})\end{array}$ \\
\hline $\begin{array}{l}\text { Olney et al. } \\
(117)\end{array}$ & $\begin{array}{l}\text { Male and Female } \\
{\mathrm{MC} 3 \mathrm{R}^{-/-} \text {and }}\end{array}$ & Not mentioned & DID paradigm (20\% EtOH) & $\begin{array}{l}\text { ICV administration } \\
\text { - MTII }(0.25,0.5 \text {, or } 1.0 \mu \mathrm{g})\end{array}$ \\
\hline
\end{tabular}

Outcomes on drinking behavio

Two-bottle choice

- Both geneotypes chose to escalate ethanol at higher percentages and drank saccharine in similar amounts

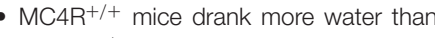
MC4R ${ }^{-1-}$ Central Administration

- MTII significantly decreased ethano drinking and food intake in $\mathrm{MC} \mathrm{R}^{+/+}$ but not $\mathrm{MC}^{-1} \mathrm{R}^{-1}$

- In wildtype mice MTII $(0.5 \mu \mathrm{g})$ reduced food, sucrose, and saccharine but no affect on water consumption Peripheral administration

- MTIl reduced food and ethanol intake regardless of genotype

CeA Administrations:

- In P rats, MTII suppressed alcohol intake $12 \mathrm{~h}$ after injection and also $24 \mathrm{~h}$ after injection

- SHU9119 also suppressed alcohol intake only after $24 \mathrm{~h}$ in P rats

- HS014 increased food intake and decreased preference for alcohol in $\mathrm{P}$ rats only at $24 \mathrm{~h}$ post-injection, but had no effect on alcohol consumption

Injections into the VTA and NAC

- MC4R agonism reduced the amount of voluntary ethanol

- In the NAc, $0.2 \mu \mathrm{g}$ of HSO14 increased ethanol consumption relative to the $0.05 \mu \mathrm{g}$ dose but not relative to saline

NAc but not LH injections showed:

- decrease in the hedonic reactions to ethanol for both concentrations

- increase in aversive responses to ethanol for the $0.75 \mu \mathrm{g}$ but not the $1.5 \mu \mathrm{g}$ dose

DID induced:

- High levels of $\mathrm{EtOH}$ consumption

- Following the first hour of DID MC3R-/mice were more sensitive to MTI showing blunted ethanol intake at all

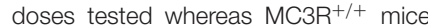
only showed blunted $\mathrm{EtOH}$ intake at $1.0 \mu \mathrm{g}$

- At $4 \mathrm{~h}$ only the MTIl was effective in both genotypes at $1.0 \mu \mathrm{g}$ 
TABLE 2 | Continued

\begin{tabular}{|c|c|c|c|c|}
\hline References & Animal model & Age and/or Weight & Drinking paradigm & Drugs \\
\hline $\begin{array}{l}\text { Navarro } \\
\text { et al. (118) }\end{array}$ & Male C57BL/6J mice & $20-25 \mathrm{~g}$ & Drinking in the Dark (20\% v/v) & $\begin{array}{l}\text { Intraperitoneal injections } \\
\text { - MTII }(0.3,1,3,10 \mathrm{mg} / \mathrm{kg}) \\
\text { - Naltrexone }(0.3,1,3,10 \mathrm{mg} / \mathrm{kg}) \\
\text { Combination injections } \\
\text { - MTII }(0.3,1,3 \mathrm{mg} / \mathrm{kg})+\text { Naltrexone } \\
\text { ( } 0.82 \text { or } 1.64 \mathrm{mg} / \mathrm{kg}) \\
\text { - Naltrexone }(0.3,1, \text { or } 3 \mathrm{mg} / \mathrm{kg})+\text { MTII } \\
\quad(0.26 \text { or } 0.52 \mathrm{mg} / \mathrm{kg})\end{array}$ \\
\hline $\begin{array}{l}\text { Carvajal } \\
\text { et al. (119) }\end{array}$ & $\begin{array}{l}\text { Male Sprague Dawley } \\
\text { rats }\end{array}$ & $\begin{array}{l}\text { PND } 25 \text { when } \\
\text { experiments began }\end{array}$ & $\begin{array}{l}\text { Binge Ethanol Protocol } \\
\text { (intraperitoneal injections of } 25 \% \mathrm{w} / \mathrm{v} \\
\text { EtOH; } 2 \text { injections every } 4 \text { days for } \\
2 \text { weeks) Intermittent ethanol } \\
\text { access ( } 20 \% \mathrm{v} / \mathrm{v} ; 3 \text { x per week for } \\
45 \text { days) }\end{array}$ & $\begin{array}{l}\text { NAc Shell injections } \\
\text { - cyclo(NH-CH} 2-\mathrm{CH}_{2} \text {-CO-His-d-Phe-Arg- } \\
\text { Trp-Glu)- } \mathrm{NH}_{2}(0.75 \text {, } \\
1.5 \mu \mathrm{g})\end{array}$ \\
\hline $\begin{array}{l}\text { Sprow et al. } \\
(120)\end{array}$ & Male C57BL6/J & $6-8$ weeks and $23 \mathrm{~g}$ & $\begin{array}{l}\text { Drinking in the Dark (DID) cycle } \\
(20 \% \mathrm{v} / \mathrm{v} E \mathrm{EtOH})\end{array}$ & $\begin{array}{l}\text { LH, DS, BNST infusions } \\
\text { - MTII (0.5 nmol) } \\
\text { - AgRP (0.1 nmol) } \\
\text { BNST infusion } \\
\text { - MTII (0.5 nmol) } \\
\text { - AgRP }(0.1 \mathrm{nmol})\end{array}$ \\
\hline
\end{tabular}

Outcomes on drinking behavior

DID ethanol intake

- Naltrexone (3 and $10 \mathrm{mg} / \mathrm{kg}$ ) and MTI (dose 1, 3, $10 \mathrm{mg} / \mathrm{kg}$ ) significantly decreased ethanol consumption and blood alcohol levels

- MC4R antagonism reduced binge-like ethanol consumption

LH injections:

- MTIl decreased ethanol consumption in the first hour but not second of DID

- AgRP increased ethanol consumption but was not changed in the LH following DID (separate experiment) BNST injections

- MTII significantly decreased ethano drinking, whereas AgRP had no effect DS injections had no effect on alcohol drinking

DID experiment

- Buproprion had no affect on drinking alone

$\mathrm{nPE}^{-/-}$mice weighed $40 \mathrm{~g}$ and $35 \mathrm{~g}(\mathrm{~m}, \mathrm{f})$ and $\mathrm{nPE}^{+/+}$mice weighed 27 and $23 \mathrm{~g}(\mathrm{~m}, \mathrm{f})$

2 main arms

Drinking in the dark (DID) with $15 \% \mathrm{v} / \mathrm{V} \mathrm{EtOH}$ for 4 days

2. Chronic intermittent access w/two bottle choice with either single injection or 4 injections on the last 4 days of testing (one injection each day)
Drugs (given intraperitoneally):

DID experiment

- Buproprion: 5, 10, $20 \mathrm{mg} / \mathrm{kg}$

- Naltrexone: 1 or $2 \mathrm{mg} / \mathrm{kg}$

- Combination (Buproprion + Naltrexone):

$5+0.5,10+1,20+1,20+2 \mathrm{mg} / \mathrm{kg}$

- HS015 $(0.5 \mu \mathrm{mol} / \mathrm{kg})$

Intermittent access

- Combination $(10+1 \mathrm{mg} / \mathrm{kg})$

- Naltrexone decreased drinking at 2 $\mathrm{mg} / \mathrm{kg}$ in both sexes

- Combination of 10+1 Buproprion and Naloxone decreased drinking greater in males than females

- Also decreased sucrose drinking in males but not females

- No effect on non-caloric reinforcer saccharin

- HS014 blocked the combination of buproprion and naloxone on drinking behaviors

- With $\mathrm{nPE}^{-1-}$ mice the combination of 10+1 Bupropion and Naltrexone had no effect on drinking Intermittent access

- Combination treatment reduced drinking in males but not females

- No tolerance to multiple administration of drug 
POMC-neuronal firing within the arcuate nucleus, likely though a dopamine-dependent mechanism (131). Therefore, bupropion may enhance melanocortin tone either through increases in POMC expression and/or activation of MC4Rs indirectly via increased $\alpha-\mathrm{MSH}$ release at terminal sites.

Pharmacological manipulation of the opioid system with bupropion supports the idea of opioid-melanocortin interaction effects on drinking behaviors. Bupropion when given at subtherapeutic dosages in conjunction with naltrexone (10 and $1 \mathrm{mg} / \mathrm{kg}$, respectively; intraperitoneal injection) reduced ethanol intake only in male mice, but not female mice (121). This effect was not seen in mice that were lacking nPE, a promotor essential for POMC production. Blockade of MC4R with HS014 blunted the combined effects of naltrexone and bupropion on alcohol intake, indicating that bupropion and naltrexone-induced decreases in ethanol drinking are dependent on MC4R (121). Further implicating an interaction between MC4R and opioid systems on alcohol drinking, Navarro and colleagues reported that a subtherapeutic dose of MTII increased the effectiveness of naltrexone by 7.6 -fold in blunting ethanol intake (118). It should be reiterated that although there is a functional interaction between the opioidergic and melanocortin systems in effects on both alcohol and pain processing, they are dichotomous. Specifically, MC4R antagonism in conjunction with opioid-receptor agonism reduces pain-like behaviors, whereas MC4R agonism and opioid-receptor antagonism seem to decrease ethanol intake in preclinical models.

\section{NEUROBIOLOGY OF ALCOHOL-INDUCED CHANGES IN PAIN PROCESSING}

\section{Bi-Directional Interactions Between Pain and Alcohol}

As mentioned above, hyperalgesia can occur following chronic alcohol exposure in humans. Males undergoing alcohol withdrawal exhibit increased sensitivity to thermal pain in peripheral sites including the hand and sternum (7). In a large study with nearly 8,000 patients that had substance use disorder, nearly $62 \%$ reported chronic pain, and of those who reported moderate to severe pain, nearly half used alcohol heavily (132). Furthermore, following serious injury, prior alcohol use was associated with persistent chronic pain outcomes following injury $(17,133)$. Importantly, neither current alcohol use (17) nor past pain intensity (133) seemed to have an effect on chronic pain a year or more following a traumatic event. This evidence likely indicates that pre-injury alcohol exposure sensitizes an individual toward a chronic pain state following a traumatic and/or stressful injury. Finally, there is evidence supporting the idea that in humans, early exposure to alcohol increases the risk for maladaptive outcomes. The National Epidemiologic Survey on Alcohol and Related Conditions (NESARC) reported that drinking prior to age 14 increased the likelihood of subsequent alcohol dependence by about 50\% (134). Although the data is limited, some studies have identified changes in pain-related outcomes following alcohol drinking in young adults. In a study with 417 adolescents being treated for alcohol and substance abuse, findings showed a significantly greater incidence of painrelated disorders in those being treated for alcohol and substance abuse than those without these diagnoses (8). Specifically, there was a higher prevalence for headaches and gastrointestinal pain, as well as reproductive systems pain (i.e., endometriosis) in females (8). In college-aged students, hypersensitivity to pressure emerges in binge drinkers who have consumed alcohol within the past 2 days relative to binge drinkers who have not consumed alcohol, and also relative to non-binge drinkers (9). Some human studies have also investigated longitudinal effects of alcohol use on pain-related outcomes. In a 3-year study, 401 individuals were followed, assessed for either problematic or non-problematic drinking levels and monitored for pain levels. In both men and women, problematic drinkers were more likely to use alcohol to manage their pain, and those with more pain-like symptoms drank more than those with less pain-like symptoms (135). This study highlights that there is a bi-directional relationship between pain and alcohol use. Collectively, the above data indicate that alcohol may augment maladaptive responses to insults, and this likely occurs in both adults and adolescent drinkers. There is also an abundance of preclinical evidence for alcohol effects on pain-related brain systems, and for the development of alcohol-induced hyperalgesia. It seems that both clinically and preclinically, when in the system, alcohol leads to analgesia (4), whereas during withdrawal when no alcohol is in the system, this produces hyperalgesia (19). Neural regions that are sensitive to alcohol and mediate nociceptive signaling are likely therapeutically relevant areas to investigate these mechanisms.

\section{A Role for MC4R Signaling in Pain-Alcohol Interactions}

As outlined above, MC4Rs likely mediate diverse effects on pain and alcohol-related behaviors via dichotomous effects at the receptor level. Specifically, antagonism of MC4R seems to reduce pain-related behaviors in preclinical models, whereas agonism reduces ethanol intake in preclinical models. A key question that has yet to be elucidated are what molecular mechanisms at the MC4R level are occurring to mediate these divergent behaviors? MC4Rs are coupled to all three major classes of $G$ proteins including $G_{s}, G_{i / o}$, and $G_{q}$ that modulate secondary messengers including cAMP, phospholipase $\mathrm{C}$-dependent signaling cascades, and the mitogen activated kinase pathways (MAPK) (83). Furthermore, MC4R couples to the inhibitory g-coupled protein $\mathrm{G}_{\mathrm{i} / \mathrm{o}}$, where activation stimulated pertussis toxin sensitive GTP $\gamma \mathrm{S}$ binding, that was also stimulated by AgRP (136). Downstream of these signaling events, MC4R-induced activation leads to MAPK activation (137, 138), AMP-kinase activation (139), and c-jun kinase activation (140). These pathways are critical for regulating substates of excitatory transmission, which are likely increased during withdrawal from alcohol, a period that is characterized by hyperalgesia $(4,18,19)$. MC4R activation increases intracellular calcium via increased cAMP production and protein kinase A activation (141). This activation leads to an upregulation of AMPA receptors via a $\mathrm{G}_{\mathrm{s}}$-PKA-dependent mechanism $(142,143)$. Furthermore, MC4R activation via this $\mathrm{G}_{s}$ 
pathway increases excitatory transmission in pain-related brain regions including the parabrachial nucleus (42). As melanocortin system activity is likely increased during the withdrawal period $(4,18,19,105)$, potentiated $G_{s}$-PKA signaling likely contributes to hyperalgesia through potentiated excitatory transmission in pain-related regions.

In addition to the canonical G-coupled protein pathways, MC4R activates downstream mediators including MAPK extracellular-signal-related kinases (ERKs) 1 and 2 in a manner that is dependent on the cell expression system and ligand binding. In HEK293 cells, ERK1/2 activation was dependent on $\mathrm{G}_{\mathrm{i} / \mathrm{o}}$ activation, as the specific inhibitor pertussis toxin reduced MC4R-mediated ERK1/2 activation (144). This is contrasted to studies conducted in GT1-1 or GT1-7 cells, that found ERK1/2 activation was unaffected by pertussis toxin, however when MC4R was stably expressed in human HEK293 cells, pertussis toxin abrogated phosphorylated ERK1/2 activation (144). Importantly, the NDP-MSH (an agonist of MC4R) mediated activation of ERK1/2 in both HEK293 and GT1-1 cells was blocked by MC4R antagonist SHU9119 (136, 144). As protein kinase A and ERK activity is associated with chronic pain-like states in rats $(71,95,145,146)$, blockade of ERK activity following MC4R antagonist HS014 treatment is associated with decreases in pain-like responses (71). These effects may be directly mediated by blockade of MC4R with selective antagonists, or they may be mediating decreases in ERK activity through a potentially different mechanism as discussed below.
The endogenous antagonist AgRP can function both as a competitive antagonist inhibiting $\alpha$-MSH binding to MC4R, and also serving as an inverse agonist, decreasing the amount of cAMP formed by MC4R (43, 147-149). In vivo data supports this notion as AGRP induces long-lasting effects on food intake beyond exposure to the drug (150). In addition to inhibition of $G_{s}$ pathways and activation of $G_{i}$ o pathways, AgRP mediates endocytosis via $\beta$-arrestins (148). Specifically, binding of either $\alpha$-MSH or AgRP induced $\beta$-arrestin-1- and 2-mediated endocytosis in HEK293 cells, and this effect was blunted in cells lacking the $\beta$-arrestin proteins (148). Importantly, this was a reversible process, where $1 \mathrm{~h}$ following treatment and removal of $\alpha-\mathrm{MSH}$ or AgRP, receptors were relocated to the plasma membrane rather than degraded, and the $\beta$ arrestin effects were confirmed in a hypothalamic cell line (148). Further complicating the effects of AgRP, a more recent studied identified that AgRP activates ERK1/2 in a $\mathrm{G}_{\mathrm{q}}$-dependent manner as phosphatidylinositol 3-kinase inhibitors decreased ERK1/2 activation following AgRP treatment in cultured GT17 hypothalamic cells (151). Like AgRP, $\alpha$-MSH induces a $\beta$ arrestin-dependent internalization that occurs when agonist ligands toward MC4R come into contact with the receptor, and this internalization occurs on the timescale of minutes (152). This $\beta$-arrestin internalization was dependent on a protein kinase A, $\beta$-arrestin-1/clathrin, but not caveolae-pit mechanisms in HEK293 and COS-1 cells (152). A two-photon microscopy study utilized rhodamine labeled antagonist SHU09119 showed

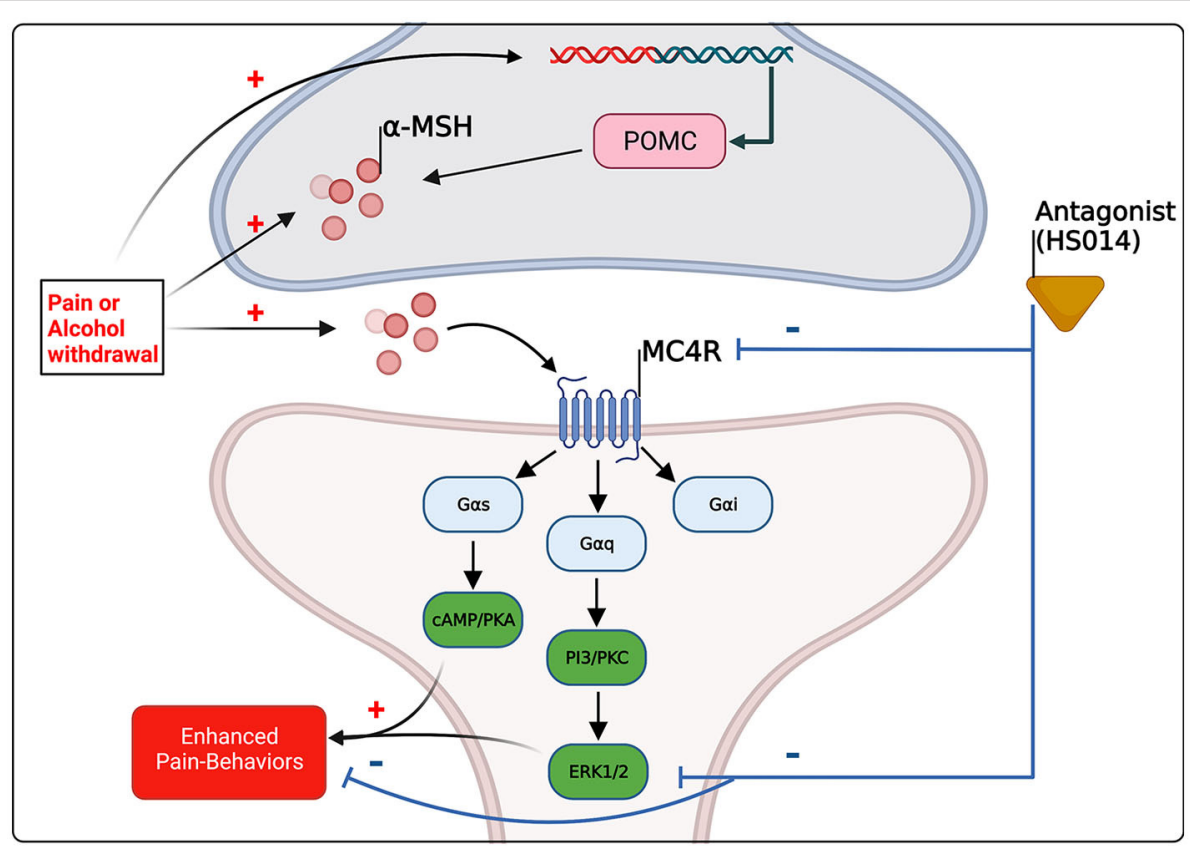

FIGURE 2 | Schematic summary of the evidence-based and hypothetical effects of pain and alcohol withdrawal on melanocortin signaling within the central nervous system, and of the effects of altered melanocortin signaling on pain-related behaviors. Pre-clinical evidence suggests that pain and alcohol withdrawal [see (98, 105)] are associated with increased melanocortin tone through increases in $\alpha-\mathrm{MSH}$ and/or POMC in brain regions implicated in pain and substance abuse, including the amygdala. MC4R couples to all three major G-coupled protein pathways, however activation of PKA and the mitogen activated protein kinase (MAPK) ERK1/2 are associated preclinically with pain-states $(145,146)$, and antagonism of MC4R reduces pain-related outcomes and results in decreases in ERK1/2 activation (72). The molecular mechanisms underlying MC4R drug effects on alcohol intake remain unclear. 
that in the presence of an antagonist, MC4R remained on the surface of HEK293 cells for $>30 \mathrm{~min}$, whereas, the agonist led to internalization within $10 \mathrm{~min}$ (153). These data indicate that antagonists likely reduce signaling through major MC4Rrelated pathways including $\mathrm{G}_{\mathrm{s}}$-cAMP-PKA, and do not recruit $\beta$ arrestin complexes, likely preventing desensitization of MC4Rs. The effects of synthetic MC4R antagonists on $G_{i}$ signaling remains to be determined and, more generally, more work is needed to determine how specific antagonists (and potentially biased ligands) modulate both $\mathrm{G}_{\mathrm{s}^{-}}$and $\mathrm{G}_{\mathrm{i}}$-signaling pathways, and how chronic alcohol and other drugs of abuse affect signaling properties.

\section{CONCLUSIONS}

How does MC4R activation mediate reductions in alcohol drinking but increases in pain-like responses, while pain drives alcohol drinking and excessive alcohol use drives pain?

One potential answer to this question is the interaction between MC4Rs and brain-derived neurotrophic factor (BDNF). MC4Rs are localized in neuronal cells $(49,154)$, astrocytes (155), and microglia (156). MC4R agonism results in BDNF production (157) and, although BDNF production is dependent on cre-Response Element Binding Protein (CREB) induction by $\mathrm{PKA}$, recent studies have indicated that MC4R may generate BDNF through exchange factors (EPACs) via ERK1/2, and not via a PKA-dependent mechanism (158). Polymorphisms within the BDNF gene are correlated with susceptibility toward addictive behaviors, including alcohol abuse (159) and chronic pain phenotypes (160). Hypofunction of BDNF may be involved in the molecular processes that underlie excessive alcohol intake (161). In individuals withdrawing from alcohol, although BDNF levels are unchanged relative to control patients, they do correlate negatively with withdrawal symptoms (i.e., lower levels of BDNF are associated with greater withdrawal symptoms) (162). In alcohol preferring male $\mathrm{P}$ rats, $\mathrm{BDNF}$ expression was decreased in the CeA relative to non-alcohol preferring NP male rats (163). Furthermore, knockdown of BNDF expression in the CeA via antisense oligodeoxynucleotides $\mathrm{CeA}$ increased alcohol intake in male Sprague-Dawley rats in a two-bottle choice paradigm, and this effect was reversed by co-infusion of BDNF in the CeA (163). Administration of BDNF into the striatum, specifically the dorsolateral and dorsomedial striatum reduces ethanol intake, and conversely, decreases in BDNF mediated by short interfering RNA, increases ethanol intake (164). We hypothesize targeting MC4Rs that preferentially activate BDNF through a PKA-independent mechanism may ameliorate alcohol-related pathologies while also reducing excitatory transmission through a $\mathrm{G}_{\mathrm{s}}$-PKA dependent pathways, leading to a reduction in painrelated behaviors.

In conclusion, the effects of alcohol and pain on MC4R are congruent; it seems that, preclinically, chronic pain increases melanocortin tone, and following chronic alcohol exposure during withdrawal, when hyperalgesia emerges, there is likely an increase in melanocortin tone (see Tables 1, 2). It should be noted however, studies focusing on chronic alcohol effects are limited and further studies are needed to resolve spatial and temporal changes. It is likely that upregulation of melanocortin tone either following pain conditions or during withdrawal promotes pain-like behaviors through $\mathrm{G}_{\mathrm{s}}$-coupled pathways, for example, via PKA activation and subsequent MAPK activation including ERK1/2 (see Figure 2). What has yet to be resolved is the dichotomous nature of MC4R signaling, where antagonism reduces pain-like behaviors yet agonism decreases alcohol drinking. Again, as postulated by Koob and colleagues, during the withdrawal/negative affect stage of addiction, pro-stress neural systems such as CRF are upregulated and potentiated $(53,55)$. As melanocortin tone is increased following stressors $(58,59)$, it may be postulated that upregulated melanocortin tone during withdrawal promotes pain-like behaviors. Agonism of MC4R decreases ethanol consumption, beyond what would be expected from mechanisms of energy homeostasis (102, 112) (also see Table 2). Therefore, the increase in melanocortin tone following withdrawal may serve to blunt further excessive alcohol intake, and lead to restoration of homeostasis. It should also be noted that alterations in melanocortin tone are likely dependent on rodent species/strain and brain region, thus, further work is necessary to characterize alterations to the melanocortin system and MC4R to obtain a more holistic view of what occurs during withdrawal. Combinations of opioid and MC4 receptor bifunctional compounds $(74,75)$ may reveal opportunities for simultaneously antagonizing opioid receptors and initiating MC4R signaling that is biased toward either $\mathrm{G}_{\mathrm{i} / \mathrm{o}}$ or $\mathrm{G}_{\mathrm{q}}$ pathways that promote BDNF production. More work is needed to fully characterize the effects of chronic alcohol exposure on the brain melanocortin system in adults and adolescents. Melanocortin-4 receptors modulate alcoholand pain-related outcomes, as well as hyperalgesia observed after chronic alcohol exposure, and thus may hold promise as a novel therapeutic target for improving quality of life in individuals living with AUD or chronic pain or both of these disorders.

\section{AUTHOR CONTRIBUTIONS}

NS and NG conceptualized the manuscript and edited the manuscript. NS drafted the manuscript. Both authors contributed to the article and approved the submitted version.

\section{FUNDING}

This work was supported by National Institutes of Health Grant F30 AA028691 to NS, R01 AA023305 to NG, and by a Merit Review Award from the United States Department of Veterans Affairs, Biomedical Laboratory Research and Development Service Grant I01 BX003451 to NG. 


\section{REFERENCES}

1. Mokdad AH, Marks JS, Stroup DF, Gerberding JL. Actual causes of death in the United States, 2000. J Am Med Assoc. (2004) 291:1238-45. doi: 10.1001/jama.291.10.1238

2. White AM, Castle IJP, Hingson RW, Powell PA. Using death certificates to explore changes in alcohol-related mortality in the United States, 1999 to 2017. Alcohol Clin Exp Res. (2020) 44:178-87. doi: 10.1111/acer.14239

3. Kim JU, Majid A, Judge R, Crook P, Nathwani R, Selvapatt N, et al. Effect of COVID-19 lockdown on alcohol consumption in patients with preexisting alcohol use disorder. Lancet Gastroenterol Hepatol. (2020) 5:886. doi: 10.1016/S2468-1253(20)30251-X

4. Egli M, Koob GF, Edwards S. Alcohol dependence as a chronic pain disorder. Neurosci Biobehav Rev. (2012) 36:2179-92. doi: 10.1016/ j.neubiorev.2012.07.010

5. Zale EL, Maisto SA, Ditre JW. Interrelations between pain and alcohol: an integrative review. Clin Psychol Rev. (2015). 37:57-71. doi: 10.1016/ j.cpr.2015.02.005

6. Sá KN, Baptista A, Matos M, Lessa I. Chronic pain and gender in Salvador population, Brazil. Pain. (2008) 139:498-506. doi: 10.1016/J.PAIN.2008.06.008

7. Jochum T, Boettger MK, Burkhardt C, Juckel G, Bär KJ. Increased pain sensitivity in alcohol withdrawal syndrome. Eur J Pain. (2010) 14:713-8. doi: 10.1016/j.ejpain.2009.11.008

8. Mertens JR, Flisher AJ, Fleming MF, Weisner CM. Medical conditions of adolescents in alcohol and drug treatment: comparison with matched controls. J Adolesc Heal. (2007) 40:173-9. doi: 10.1016/ j.jadohealth.2006.09.021

9. You DS, Hahn HA, Welsh TH, Meagher MW. Hyperalgesia after a drinking episode in young adult binge drinkers: a cross-sectional study. Alcohol Alcohol. (2020) 55:608-15. doi: 10.1093/ALCALC/AGAA035

10. Crews FT, Robinson DL, Chandler LJ, Ehlers CL, Mulholland PJ, Pandey SC, et al. Mechanisms of persistent neurobiological changes following adolescent alcohol exposure: NADIA consortium findings. Clin Exp Res. (2019) 43:1806-22. doi: 10.1111/acer.14154

11. Spear LP, Swartzwelder HS. Adolescent alcohol exposure and persistence of adolescent-typical phenotypes into adulthood: a mini-review. Neurosci Biobehav Rev. (2014) 45:1-8. doi: 10.1016/j.neubiorev.2014.04.012

12. Crews FT, Vetreno RP, Broadwater MA, Robinson DL. Adolescent alcohol exposure persistently impacts adult neurobiology and behavior. Pharmacol Rev. (2016) 68:1074-109. doi: 10.1124/pr.115.012138

13. Grant BF, Dawson DA. Age at onset of alcohol use and its association with DSM-IV alcohol abuse and dependence: results from the national longitudinal alcohol epidemiologic survey. J Subst Abuse. (1997) 9:103-10. doi: 10.1016/S0899-3289(97)90009-2

14. Edwards AC, Heron J, Dick DM, Hickman M, Lewis G, Macleod J, et al. Adolescent alcohol use is positively associated with later depression in a population-based U.K. cohort. J Stud Alcohol Drugs. (2014) 75:758-65. doi: 10.15288 /jsad.2014.75.758

15. Koob GF. Negative reinforcement in drug addiction: the darkness within. Curr Opin Neurobiol. (2013) 23:559-63. doi: 10.1016/J.CONB.2013. 03.011

16. Cheng Y, Macera CA, Davis DR, Ainsworth BE, Troped PJ, Blair SN. Physical activity and self-reported, physician-diagnosed osteoarthritis: is physical activity a risk factor? J Clin Epidemiol. (2000) 53:315-22. doi: 10.1016/S0895-4356(99)00168-7

17. Holmes A, Williamson O, Hogg M, Arnold C, Prosser A, Clements J, et al. Predictors of pain severity 3 months after serious injury. Pain Med. (2010) 11:990-1000. doi: 10.1111/j.1526-4637.2010.00890.x

18. Dina OA, Messing RO, Levine JD. Ethanol withdrawal induces hyperalgesia mediated by PKCE. Eur J Neurosci. (2006) 24:197-204. doi: 10.1111/j.1460-9568.2006.04886.x

19. Gatch MB. Ethanol withdrawal and hyperalgesia. Curr Drug Abuse Rev. (2009) 2:41-50. doi: 10.2174/1874473710902010041

20. Roltsch Hellard EA, Impastato RA, Gilpin NW. Intra-cerebral and intra-nasal melanocortin-4 receptor antagonist blocks withdrawal hyperalgesia in alcohol-dependent rats. Addict Biol. (2017) 22:692-701. doi: $10.1111 / \mathrm{adb} .12360$
21. Avegno EM, Lobell TD, Itoga CA, Baynes BB, Whitaker AM, Weera MM, et al. Central amygdala circuits mediate hyperalgesia in alcohol-dependent rats. J Neurosci. (2018) 38:7761-73. doi: 10.1523/JNEUROSCI.0483-18.2018

22. Pradhan AA, Tipton AF, Zhang H, Akbari A, Pandey SC. Effect of histone deacetylase inhibitor on ethanol withdrawal-induced hyperalgesia in rats. Int J Neuropsychopharmacol. (2019) 22:523. doi: 10.1093/IJNP/PYZ031

23. Cucinello-Ragland JA, Mitchell-Cleveland R, Bradley Trimble W, Urbina AP, Yeh AY, Edwards KN, et al. Alcohol amplifies cingulate cortex signaling and facilitates immobilization-induced hyperalgesia in female rats. Neurosci Lett. (2021) 761:136119. doi: 10.1016/J.NEULET.2021.136119

24. Apkarian AV, Neugebauer V, Koob G, Edwards S, Levine JD, Ferrari L, et al. Neural mechanisms of pain and alcohol dependence. Pharmacol Biochem Behav. (2013) 112:34-41. doi: 10.1016/j.pbb.2013.09.008

25. Jacobowitz DM, O'Donohue TL. $\alpha$-Melanocyte stimulating hormone: immunohistochemical identification and mapping in neurons of rat brain. Proc Natl Acad Sci USA. (1978) 75:6300-4. doi: 10.1073/pnas.75.12.6300

26. Mountjoy KG, Mortrud MT, Low MJ, Simerly RB, Cone RD. Localization of the melanocortin-4 receptor (MC4-R) in neuroendocrine and autonomic control circuits in the brain. Mol Endocrinol. (1994) 8:1298-308. doi: 10.1210/mend.8.10.7854347

27. Adan RAH, Gispen WH. Melanocortins and the brain: from effects via receptors to drug targets. Eur J Pharmacol. (2000) 405:13-24. doi: 10.1016/S0014-2999(00)00537-9

28. Kishi T, Aschkenasi CJ, Lee CE, Mountjoy KG, Saper CB, Elmquist JK. Expression of melanocortin 4 receptor mRNA in the central nervous system of the rat. J Comp Neurol. (2003) 457:213-35. doi: 10.1002/cne.10454

29. Cone RD. Anatomy and regulation of the central melanocortin system. Nat Neurosci. (2005) 8:571-8. doi: 10.1038/nn1455

30. Navarro M. The role of the melanocortin system in drug and alcohol abuse. Int Rev Neurobiol. (2017) 136:121-50. doi: 10.1016/bs.irn.2017.06.009

31. Wilkinson CW. Roles of acetylation and other post-translational modifications in melanocortin function and interactions with endorphins. Peptides. (2006) 27:453-71. doi: 10.1016/j.peptides.2005.05.029

32. Cain BM, Connolly K, Blum A, Vishnuvardham D, Marchand JE, Beinfeld MC. Distribution and colocalization of cholecystokinin with the prohormone convertase enzymes PC1, PC2, and PC5 in rat brain. J Comp Neurol. (2003) 467:307-25. doi: 10.1002/CNE.10924

33. Lynch DR, Braas KM, Mutton JC, Snyder SH. Carboxypeptidase $\mathrm{E}$ (CPE): immunocytochemical localization in the rat central nervous system and pituitary gland. J Neurosci. (1990) 10:1592-9. doi: 10.1523/jneurosci.10-05-01592.1990

34. MacCumber M, Snyder S, Ross C. Carboxypeptidase E (enkephalin convertase): mRNA distribution in rat brain by in situ hybridization. $J$ Neurosci. (1990) 10:2850-60. doi: 10.1523/jneurosci.10-08-02850.1990

35. Jeong JK, Diano S. Prolyl carboxypeptidase mRNA expression in the mouse brain. Brain Res. (2014) 1542:85-92. doi: 10.1016/j.brainres.2013.10.031

36. Alvaro JD, Tatro JB, Quillan JM, Fogliano M, Eisenhard M, Lerner MR, et al. Morphine down-regulates melanocortin-4 receptor expression in brain regions that mediate opiate addiction. Mol Pharmacol. (1996) 50:583-91.

37. Ericson MD, Lensing CJ, Fleming KA, Schlasner KN, Doering SR, HaskellLuevano C. Bench-top to clinical therapies: a review of melanocortin ligands from 1954 to 2016. Biochim Biophys Acta. (2017) 1863:2414-35. doi: 10.1016/j.bbadis.2017.03.020

38. Sharma S, Garfield AS, Shah B, Kleyn P, Ichetovkin I, Moeller IH, et al. Molecules current mechanistic and pharmacodynamic understanding of melanocortin-4 receptor activation. Molecules. (2019) 24:1892. doi: 10.3390/molecules24101892

39. Jolles J, Rompa-Barendregt J, Gispen WH. ACTH-induced excessive grooming in the rat: the influence of environmental and motivational factors. Horm Behav. (1979) 12:60-72. doi: 10.1016/0018-506X(79)90027-8

40. Versteeg DHG, Van Bergen P, Adan RAH, De Wildt DJ. Melanocortins and cardiovascular regulation. Eur J Pharmacol. (1998) 360:1-14. doi: 10.1016/S0014-2999(98)00615-3

41. Catania A, Gatti S, Colombo G, Lipton JM. Targeting melanocortin receptors as a novel strategy to control inflammation. Pharmacol Rev. (2004) 56:1-29. doi: 10.1124/pr.56.1.1

42. Shah BP, Vong L, Olson DP, Koda S, Krashes MJ, Ye C, et al. MC4Rexpressing glutamatergic neurons in the paraventricular hypothalamus 
regulate feeding and are synaptically connected to the parabrachial nucleus. Proc Natl Acad Sci USA. (2014) 111:13193-8. doi: 10.1073/pnas.1407843111

43. Yang Y, Thompson DA, Dickinson CJ, Wilken J, Barsh GS, Kent SBH, et al. Characterization of agouti-related protein binding to melanocortin receptors. Mol Endocrinol. (1999) 13:148-55. doi: 10.1210/MEND.13.1.0223

44. Krivoy WA, Kroeger DC, Zimmermann E. Neuropeptides: influence of acute and chronic effects of opiates. Psychoneuroendocrinology. (1977) 2:43-51. doi: 10.1016/0306-4530(77)90030-0

45. Krivoy WA, Zimmerman E. An effect of $\beta$-melanocyte stimulating hormone ( $\beta$-MSH) on $\alpha$-motoneurones of cat spinal cord. Eur J Pharmacol. (1977) 46:315-22. doi: 10.1016/0014-2999(77)90225-4

46. Alvaro JD, Tatro JB, Duman RS. Melanocortins and opiate addiction. Life Sci. (1997) 61:1-9. doi: 10.1016/S0024-3205(97)00029-5

47. Starowicz K, Sieja A, Bilecki W, Obara I, Przewlocka B. The effect of morphine on MC4 and CRF receptor mRNAs in the rat amygdala and attenuation of tolerance after their blockade. Brain Res. (2003) 990:113-9. doi: 10.1016/S0006-8993(03)03444-9

48. Starowicz K, Bilecki W, Sieja A, Przewlocka B, Przewlocki R. Melanocortin 4 receptor is expressed in the dorsal root ganglions and down-regulated in neuropathic rats. Neurosci Lett. (2004) 358:79-82. doi: 10.1016/j.neulet.2003.12.096

49. Li ZX, Liu BW, He ZG, Xiang HB. Melanocortin-4 receptor regulation of pain. Biochim Biophys Acta. (2017) 1863(10 Pt A):2515-22. doi: 10.1016/j.bbadis.2017.05.021

50. Lerma-Cabrera JM, Carvajal F, Garbutt JC, Navarro M, Thiele TE. The melanocortin system as a potential target for treating alcohol use disorders: a review of pre-clinical data. Brain Res. (2020) 1730:146628. doi: 10.1016/j.brainres.2019.146628

51. Flores-Bastías O, Adriasola-Carrasco A, Karahanian E. Activation of melanocortin-4 receptor inhibits both neuroinflammation induced by early exposure to ethanol and subsequent voluntary alcohol intake in adulthood in animal models: is BDNF the key mediator? Front Cell Neurosci. (2020) 14:5. doi: $10.3389 /$ fncel.2020.00005

52. Kokare DM, Kyzar EJ, Zhang H, Sakharkar AJ, Pandey SC. Adolescent alcohol exposure-induced changes in alpha-melanocyte stimulating hormone and neuropeptide y pathways via histone acetylation in the brain during adulthood. Int J Neuropsychopharmacol. (2017) 20:758-68. doi: 10.1093/ijnp/pyx041

53. Koob GF, Le Moal M. Plasticity of reward neurocircuitry and the "dark side" of drug addiction. Nat Neurosci. (2005) 8:1442-4. doi: 10.1038/nn1105-1442

54. Koob GF, Le Moal M. Drug abuse: hedonic homeostatic dysregulation. Science. (1997) 278:52-8. doi: 10.1126/science.278.5335.52

55. Koob GF, Volkow ND. Neurocircuitry of addiction. Neuropsychopharmacology. (2010) 35:217-38. doi: 10.1038/npp.2009.110

56. Liu J, Garza JC, Li W, Lu X-YY. Melanocortin-4 receptor in the medial amygdala regulates emotional stress-induced anxiety-like behaviour, anorexia and corticosterone secretion. Int J Neuropsychopharmacol. 16:10520. doi: $10.1017 /$ S146114571100174X

57. Yamano Y, Yoshioka M, Toda Y, Oshida Y, Chaki S, Hamamoto K, et al. Regulation of CRF, POMC and MC4R gene expression after electrical foot shock stress in the rat amygdala and hypothalamus. J Vet Med Sci. (2004) 66:1323-7. doi: 10.1292/jvms.66.1323

58. Chaki S, Ogawa SI, Toda Y, Funakoshi T, Okuyama S. Involvement of the melanocortin MC4 receptor in stress-related behavior in rodents. Eur J Pharmacol. (2003) 474:95-101. doi: 10.1016/S0014-2999(03)02033-8

59. Taketoshi O, Shigeyuki C. Melanocortin-4 receptor antagonists for the treatment of depression and anxiety disorders. Curr Top Med Chem. (2007) 7:1145-51. doi: 10.2174/156802607780906618

60. Sandman CA, Kastin AJ. Intraventricular administration of MSH induces hyperalgesia in rats. Peptides. (1981) 2:231-3. doi: 10.1016/S0196-9781(81)80040-X

61. Beltramo M, Campanella M, Tarozzo G, Fredduzzi S, Corradini L, Forlani A, et al. Gene expression profiling of melanocortin system in neuropathic rats supports a role in nociception. Mol Brain Res. (2003) 118:111-8. doi: 10.1016/j.molbrainres.2003.08.001

62. Bellasio S, Nicolussi E, Bertorelli R, Reggiani A. Melanocortin receptor agonists and antagonists modulate nociceptive sensitivity in the mouse formalin test. Eur J Pharmacol. (2003) 482:127-32. doi: 10.1016/j.ejphar.2003.09.017

63. Ercil NE, Galici R, Kesterson RA. HS014, a selective melanocortin-4 (MC4) receptor antagonist, modulates the behavioral effects of morphine in mice. Psychopharmacology. (2005) 180:279-85. doi: 10.1007/s00213-005-2166-x

64. Zvejniece L, Muceniece R, Krigere L, Dambrova M, Klusa VZ. The differential influences of melanocortins on nociception in the formalin and tail flick tests. Pharmacol Biochem Behav. (2006) 85:287-91. doi: 10.1016/j.pbb.2006.08.001

65. Vrinten DH, Gispen WH, Groen GJ, Adan RAH. Antagonism of the melanocortin system reduces cold and mechanical allodynia in mononeuropathic rats. J Neurosci. (2000) 20:8131-7. doi: 10.1523/jneurosci.20-21-08131.2000

66. Vrinten DH, Gispen WH, Kalkman CJ, Adan RAH, DH V, WH G, et al. Interaction between the spinal melanocortin and opioid systems in a rat model of neuropathic pain. Anesthesiology. (2003) 99:449-54. doi: 10.1097/00000542-200308000-00028

67. Starowicz K, Przewlocki R, Gispen WH, Przewlocka B. Modulation of melanocortin-induced changes in spinal nociception by $\mu$-opioid receptor agonist and antagonist in neuropathic rats. Neuroreport. (2002) 13:2447-52. doi: 10.1097/00001756-200212200-00015

68. Starowicz K, Obara I, Przewłocki R, Przewlocka B. Inhibition of morphine tolerance by spinal melanocortin receptor blockade. Pain. (2005) 117:40111. doi: 10.1016/j.pain.2005.07.003

69. Starowicz K, Mousa SA, Obara I, Chocyk A, Przewocki R, Wêdzony K, et al. Peripheral antinociceptive effects of MC4 receptor antagonists in a rat model of neuropathic pain-a biochemical and behavioral study. Pharmacol Rep. (2009) 61:1086-95. doi: 10.1016/s1734-1140(09)70171-9

70. Kalange AS, Kokare DM, Singru PS, Upadhya MA, Chopde CT, Subhedar NK. Central administration of selective melanocortin 4 receptor antagonist HS014 prevents morphine tolerance and withdrawal hyperalgesia. Brain Res. (2007) 1181:10-20. doi: 10.1016/j.brainres.2007.08.054

71. Chu H, Xia J, Yang Z, Gao J. Melanocortin 4 receptor induces hyperalgesia and allodynia after chronic constriction injury by activation of p38 MAPK in DRG. Int J Neurosci. (2012) 122:74-81. doi: 10.3109/00207454.2011.630542

72. Chu $\mathrm{H}$, Sun J, Xu H, Niu Z, Xu M. Effect of periaqueductal gray melanocortin 4 receptor in pain facilitation and glial activation in rat model of chronic constriction injury. Neurol Res. (2012) 34:871-88. doi: 10.1179/1743132812Y.0000000085

73. Zhao Y, Xin Y, Chu H. MC4R is involved in neuropathic pain by regulating JNK signaling pathway after chronic constriction injury. Front Neurosci. (2019) 13:919. doi: 10.3389/fnins.2019.00919

74. Starnowska-Sokół J, Piotrowska A, Bogacka J, Makuch W, Mika J, Witkowska E, et al. Novel hybrid compounds, opioid agonist+melanocortin 4 receptor antagonist, as efficient analgesics in mouse chronic constriction injury model of neuropathic pain. Neuropharmacology. (2020) 178:108232. doi: 10.1016/j.neuropharm.2020.108232

75. Piotrowska A, Starnowska-Sokół J, Makuch W, Mika J, Witkowska E, Tymecka D, et al. Novel bifunctional hybrid compounds designed to enhance the effects of opioids and antagonize the pronociceptive effects of nonopioid peptides as potent analgesics in a rat model of neuropathic pain. Pain. (2021) 162:432-45. doi: 10.1097/j.pain.0000000000002045

76. Robinson KC, Kemény L V, Fell GL, Hermann AL, Allouche J, Ding W, et al. Reduced MC4R signaling alters nociceptive thresholds associated with red hair. Sci Adv. (2021) 7:eabd1310. doi: 10.1126/sciadv.abd1310

77. Klawonn AM, Fritz M, Nilsson A, Bonaventura J, Shionoya K, Mirrasekhian E, et al. Motivational valence is determined by striatal melanocortin 4 receptors. J Clin Invest. (2018) 128:3160-70. doi: 10.1172/JCI97854

78. Williams DW, Lipton JM, Giesecke AH. Influence of centrally administered peptides on ear withdrawal from heat in the rabbit. Peptides. (1986) 7:1095100. doi: 10.1016/0196-9781(86)90139-7

79. Hendrik Gispen W, Buitelaar J, Wiegant VM, Terenius L, De Wied D. Interaction between acth fragments, brain opiate receptors and morphine-induced analgesia. Eur J Pharmacol. (1976) 39:393-7. doi: 10.1016/0014-2999(76)90150-3

80. Gispen WH, Van Wimersma Greidanus TB, Waters-Ezrin C, Zimmermann E, Krivoy WA, de Wied D. Influence of peptides on reduced response of 
rats to electric footshock after acute administration of morphine. Eur $J$ Pharmacol. (1975) 33:99-105. doi: 10.1016/0014-2999(75)90143-0

81. Jozic I, Stojadinovic O, Kirsner RSF, Tomic-Canic M. Skin under the (Spot)light: cross-talk with the central hypothalamic-pituitary-adrenal (HPA) axis. J Invest Dermatol. (2015) 135:1469-71. doi: 10.1038/jid.2015.56

82. Schiöth HB, Muceniece R, Wikberg JES. Characterisation of the melanocortin 4 receptor by radioligand binding. Pharmacol Toxicol. (1996) 79:161-5. doi: 10.1111/j.1600-0773.1996.tb00261.x

83. Tao YX. The melanocortin-4 receptor: physiology, pharmacology, and pathophysiology. Endocr Rev. (2010) 31:506-43. doi: 10.1210/er.2009-0037

84. Eipper BA, Mains RE. Structure and biosynthesis of proadrenocorticotropin/endorphin and related peptides. Endocr Rev. (1980) 1:1-27. doi: 10.1210/edrv-1-1-1

85. Noble M, Treadwell JR, Tregear SJ, Coates VH, Wiffen PJ, Akafomo C, et al. Long-term opioid management for chronic noncancer pain. (2018) 2010:CD006605. doi: 10.1002/14651858.CD006605.pub2

86. Yi P, Pryzbylkowski P. Opioid Induced Hyperalgesia. Pain Med. (2015) 16(Suppl_1):S32-6. doi: 10.1111/pme.12914

87. Contreras PC, Takemori AE. Antagonism of morphine-induced analgesia, tolerance and dependence by alpha-melanocyte-stimulating hormone. $J$ Pharmacol Exp Ther. (1984) 229:21-6.

88. Winter CA, Flataker L. The effect of cortisone, desoxycorticosterone, and andrenocorticotrophic hormone upon the responses of animals to analgesic drugs. J Pharmacol Exp Ther. (1951) 103:93-105.

89. Chen M, He Z, Liu S-G, Xiang H. Motor cortex-periaqueductal gray-rostral ventromedial medulla neuronal circuitry may involve in modulation of nociception by melanocortinergic-opioidergic signaling. PLoS ONE. (2016) 9:e89486. doi: 10.1371/journal.pone.0089486

90. Neugebauer V. 5. Amygdala pain mechanisms HHS public access. Handb Exp Pharmacol. (2015) 227:261-84. doi: 10.1007/978-3-662-46450-2_13

91. Wilson TD, Valdivia S, Khan A, Ahn HS, Adke AP, Gonzalez SM, et al. Dual and opposing functions of the central amygdala in the modulation of pain. Cell Rep. (2019) 29:332-46.e5. doi: 10.1016/j.celrep.2019.09.011

92. Ji G, Sun H, Fu Y, Li Z, Pais-Vieira M, Galhardo V, et al. Cognitive impairment in pain through amygdala-driven prefrontal cortical deactivation. J Neurosci. (2010) 30:5451-64. doi: 10.1523/ JNEUROSCI.0225-10.2010

93. Jackson KC. Pharmacotherapy for neuropathic pain. Pain Pract. (2006) 6:27-33. doi: 10.1111/j.1533-2500.2006.00055.x

94. Vrinten DH, Adan RAH, Groen GJ, Gispen WH. Chronic blockade of melanocortin receptors alleviates allodynia in rats with neuropathic pain. Anesth Analg. (2001) 93:1572-7. doi: 10.1097/00000539-200112000-00052

95. Chu H, Xia J, Xu H, Yang Z, Gao J, Liu S. Melanocortin 4 receptor mediates neuropathic pain through p38mapk in spinal cord. Can J Neurol Sci. (2012) 39:458-64. doi: 10.1017/S0317167100013962

96. De Waele P, Gianoulakis C. Enhanced activity of the brain beta-endorphin system by free-choice ethanol drinking in C57BL/6 but not DBA/2 mice. Eur J Pharmacol. (1994) 258:119-29. doi: 10.1016/0014-2999(94)90064-7

97. Rasmussen DD, Boldt BM, Bryant CA, Mitton DR, Larsen SA, Wilkinson CW. Chronic daily ethanol and withdrawal: 1. Long-term changes in the hypothalamo-pituitary-adrenal axis. Alcohol Clin Exp Res. (2000) 24:183649. doi: 10.1111/j.1530-0277.2000.tb01988.x

98. Rasmussen DD, Boldt BM, Wilkinson CW, Mitton DR. Chronic daily ethanol and withdrawal: 3. Forebrain pro-opiomelanocortin gene expression and implications for dependence, relapse, and deprivation effect. Alcohol Clin Exp Res. (2002) 26:535-46. doi: 10.1111/J.1530-0277.2002.TB0 2572.X

99. Scanlon MN, Lazar-Wesley E, Grant KA, Kunos G. Proopiomelanocortin messenger RNA is decreased in the mediobasal hypothalamus of rats made dependent on ethanol. Alcohol Clin Exp Res. (1992) 16:1147-51. doi: 10.1111/J.1530-0277.1992.TB00711.X

100. Dave JR, Eiden LE, Karanian J, Eskda RL. Ethanol exposure decreases pituitary corticotropin-releasing factor binding, adenylate cyclase activity, proopiomelanocortin biosynthesis, and plasma $\beta$-endorphin levels in the rat. Endocrinology. (1986) 118:280-6. doi: 10.1210/ENDO-118-1-280

101. Zhou Y, Franck J, Spangler R, Maggos CE, Ho A, Kreek MJ. Reduced Hypothalamic POMC and anterior pituitary CRF1 receptor mRNA levels after acute, but not chronic, daily "binge" intragastric alcohol administration. Alcohol Clin Exp Res. (2000) 24:1575-82. doi: 10.1111/J.1530-0277.2000.TB04577.X

102. Navarro M, Cubero I, Knapp DJ, Breese GR, Thiele TE. Decreased immunoreactivity of the melanocortin neuropeptide $\alpha$-melanocytestimulating hormone ( $\alpha$-MSH) after chronic ethanol exposure in Sprague-Dawley rats. Alcohol Clin Exp Res. (2008) 32:266-76. doi: 10.1111/j.1530-0277.2007.00578.x

103. Rainero I, De Gennaro T, Visentin G, Brunetti E, Cerrato P, Torre E, et al. Effects of chronic ethanol treatment on $\alpha-\mathrm{MSH}$ concentrations in rat brain and pituitary. Neuropeptides. (1990) 15:139-41. doi: 10.1016/0143-4179(90)90145-O

104. Cubero I, Navarro M, Carvajal F, Lerma-Cabrera JM, Thiele TE. Ethanolinduced increase of agouti-related protein (AgRP) immunoreactivity in the arcuate nucleus of the hypothalamus of C57BL/6J, but not 129/SvJ, inbred mice. Alcohol Clin Exp Res. (2010) 34:693-701. doi: 10.1111/J.1530-0277.2009.01138.X

105. Kokare DM, Singru PS, Dandekar MP, Chopde CT, Subhedar NK. Involvement of alpha-melanocyte stimulating hormone $(\alpha-\mathrm{MSH})$ in differential ethanol exposure and withdrawal related depression in rat: neuroanatomical-behavioral correlates. Brain Res. (2008) 1216:53-67. doi: 10.1016/j.brainres.2008.03.064

106. Olney JJ, Navarro M, Thiele TE. Targeting central melanocortin receptors: a promising novel approach for treating alcohol abuse disorders. Front Neurosci. (2014) 8:128. doi: 10.3389/fnins.2014.00128

107. Navarro M, Cubero I, Thiele TE. Decreased immunoreactivity of the polypeptide precursor pro-opiomelanocortin (POMC) and the prohormone convertase PC1/3 after chronic ethanol exposure in Sprague-Dawley rats. Alcohol Clin Exp Res. (2013) 37:399. doi: 10.1111/J.1530-0277.2012.01951.X

108. Ploj K, Roman E, Kask A, Hyytiä P, Schiöth H, Wikberg J, et al. Effects of melanocortin receptor ligands on ethanol intake and opioid peptide levels in alcohol-preferring AA rats. Brain Res Bull. (2002) 59:97-104. doi: 10.1016/S0361-9230(02)00844-4

109. Navarro M, Cubero I, Knapp DJ, Thiele TE. MTII-induced reduction of voluntary ethanol drinking is blocked by pretreatment with AgRP-(83-132). Neuropeptides. (2003) 37:338-44. doi: 10.1016/J.NPEP.2003.10.003

110. Navarro M, Cubero I, Chen AS, Chen HY, Knapp DJ, Breese GR, et al. Effects of melanocortin receptor activation and blockade on ethanol intake: A possible role for the melanocortin-4 receptor. Alcohol Clin Exp Res. (2005) 29:949-57. doi: 10.1097/01.ALC.0000167740.19702.8C

111. Polidori C, Geary N, Massi M. Effect of the melanocortin receptor stimulation or inhibition on ethanol intake in alcohol-preferring rats. Peptides. (2006) 27:144-9. doi: 10.1016/J.PEPTIDES.2005.07.008

112. Navarro M, Cubero I, Ko L, Thiele TE. Deletion of agouti-related protein blunts ethanol self-administration and binge-like drinking in mice. Genes, Brain Behav. (2009) 8:450-8. doi: 10.1111/j.1601-183X.2009.00493.x

113. Navarro M, Lerma-Cabrera JM, Carvajal F, Lowery EG, Cubero I, Thiele TE. Assessment of voluntary ethanol consumption and the effects of a melanocortin (MC) receptor agonist on ethanol intake in mutant C57BL/6 J mice lacking the MC-4 receptor. Alcohol Clin Exp Res. (2011) 35:1058. doi: 10.1111/J.1530-0277.2011.01438.X

114. York DA, Boghossian S, Park-York M. Melanocortin activity in the amygdala influences alcohol intake. Pharmacol Biochem Behav. (2011) 98:112-9. doi: 10.1016/j.pbb.2010.12.010

115. Lerma-Cabrera JM, Carvajal F, De la Torre L, De la Fuente L, Navarro $\mathrm{M}$, Thiele TE, et al. Control of food intake by MC4-R signaling in the lateral hypothalamus, nucleus accumbens shell and ventral tegmental area: interactions with ethanol. Behav Brain Res. (2012) 234:51-60. doi: 10.1016/J.BBR.2012.06.006

116. JM L-C, F C, G C, M G, M N, TE T, et al. MC4-R signaling within the nucleus accumbens shell, but not the lateral hypothalamus, modulates ethanol palatability in rats. Behav Brain Res. (2013) 239:51-4. doi: 10.1016/J.BBR.2012.10.055

117. Olney JJ, Sprow GM, Navarro M, Thiele TE. The protective effects of the melanocortin receptor (MCR) agonist, melanotan-II (MTII), against bingelike ethanol drinking are facilitated by deletion of the MC3 receptor in mice. Neuropeptides. (2014) 48:47. doi: 10.1016/J.NPEP.2013.11.001

118. Navarro M, Carvajal F, Lerma-Cabrera JM, Cubero I, Picker MJ, Thiele TE. Evidence that melanocortin receptor agonist melanotan-II synergistically 
augments the ability of naltrexone to blunt binge-like ethanol intake in male C57BL/6J mice. Alcohol Clin Exp Res. (2015) 39:1425-33. doi: 10.1111 acer.12774

119. Carvajal F, Lerma-Cabrera JM, Alcaraz-Iborra M, Navarro M, Thiele TE, Cubero I, et al. Nucleus accumbens MC4-R stimulation reduces food and ethanol intake in adult rats regardless of binge-like ethanol exposure during adolescence. Front. Behav. Neurosci. (2017) 11:167. doi: 10.3389/fnbeh.2017.00167

120. Sprow GM, Rinker JA, Lowery-Gointa EG, Sparrow AM, Navarro M, Thiele $\mathrm{TE}$, et al. Lateral hypothalamic melanocortin receptor signaling modulates binge-like ethanol drinking in C57BL/6J mice. Addict Biol. (2016) 21:835-46. doi: 10.1111/adb.12264

121. Zhou Y, Leri F, Low MJ, Kreek MJ. Sex differences in the effect of bupropion and naltrexone combination on alcohol drinking in mice. Pharmacol Biochem Behav. (2019) 181:28. doi: 10.1016/J.PBB.2019.04.004

122. Fan W, Boston BA, Kesterson RA, Hruby VJ, Cone RD. Role of melanocortinergic neurons in feeding and the agouti obesity syndrome. Nature. (1997) 385:165-8. doi: 10.1038/385165a0

123. Giraudo S, Billington C, Levine A. Feeding effects of hypothalamic injection of melanocortin 4 receptor ligands. Brain Res. (1998) 809:302-6. doi: 10.1016/S0006-8993(98)00837-3

124. Shelkar G, Atmaram K, Singh U, Singru P, Subhedar N, Dadasaheb K. Alphamelanocyte stimulating hormone modulates ethanol self-administration in posterior ventral tegmental area through melanocortin-4 receptors. Addict Biol. (2015) 20:302-15. doi: 10.1111/ADB.12126

125. Modesto-Lowe V, Fritz EM. The opioidergic-alcohol link. CNS Drugs. (2012) 19:693-707. doi: 10.2165/00023210-200519080-00005

126. Coonfield DL, Hill KG, Kaczmarek HJ, Ferraro FM, Kiefer SW. Low doses of naltrexone reduce palatability and consumption of ethanol in outbred rats. Alcohol. (2002) 26:43-7. doi: 10.1016/S0741-8329(01)00180-X

127. Hill KG, Kiefer SW. Naltrexone treatment increases the aversiveness of alcohol for outbred rats. Alcohol Clin Exp Res. (1997) 21:637-41. doi: 10.1111/J.1530-0277.1997.TB03815.X

128. O'Malley S, Jaffe A, Chang G, Schottenfeld R, Meyer R, Rounsaville B. Naltrexone and coping skills therapy for alcohol dependence. A controlled study. Arch Gen Psychiatry. (1992) 49:881-7. doi: 10.1001/ARCHPSYC.1992.01820110045007

129. Levy AM, Daniels S, Hudson R, Horman T, Flynn A, Zhou Y, et al. Bupropion and naltrexone combination alters high fructose corn syrup self-administration and gene expression in rats. Neuropharmacology. (2018) 135:547-54. doi: 10.1016/J.NEUROPHARM.2018.01.035

130. Reece A. Hypothalamic opioid-melanocortin appetitive balance and addictive craving. Med Hypotheses. (2011) 76:132-7. doi: 10.1016/J.MEHY.2010.09.002

131. Billes SK, Sinnayah P, Cowley MA. Naltrexone/bupropion for obesity: an investigational combination pharmacotherapy for weight loss. Pharmacol Res. (2014). 84:1-11. doi: 10.1016/j.phrs.2014.04.004

132. Potter J, Prather K, Weiss R. Physical pain and associated clinical characteristics in treatment-seeking patients in four substance use disorder treatment modalities. Am J Addict. (2008) 17:121-5. doi: 10.1080/10550490701862902

133. Castillo RC, MacKenzie EJ, Wegener ST, Bosse MJ. Prevalence of chronic pain seven years following limb threatening lower extremity trauma. Pain. (2006) 124:321-9. doi: 10.1016/J.PAIN.2006.04.020

134. Hingson RW, Heeren T, Winter MR. Age at drinking onset and alcohol dependence: age at onset, duration, and severity. Arch Pediatr Adolesc Med. (2006) 160:739-46. doi: 10.1001/ARCHPEDI.160.7.739

135. Brennan P, Schutte K, Moos R. Pain and use of alcohol to manage pain: prevalence and 3-year outcomes among older problem and non-problem drinkers. Addiction. (2005) 100:777-86. doi: 10.1111/J.1360-0443.2005.01074.X

136. Büch TRH, Heling D, Damm E, Gudermann T, Breit A. Pertussis toxinsensitive signaling of melanocortin-4 receptors in hypothalamic GT1-7 cells defines agouti-related protein as a biased agonist. J Biol Chem. (2009) 284:26411. doi: 10.1074/JBC.M109.039339

137. Vongs A, Lynn NM, Rosenblum CI. Activation of MAP kinase by MC4-R through PI3 kinase. Regul Pept. (2004) 120:113-8. doi: 10.1016/J.REGPEP.2004.02.018
138. Patten CS, Daniels D, Suzuki A, Fluharty SJ, Yee DK. Structural and signaling requirements of the human melanocortin 4 receptor for MAP kinase activation. Regul Pept. (2007) 142:111-22. doi: 10.1016/J.REGPEP.2007.02.005

139. Molden BM, Cooney KA, West K, Ploeg LHT Van Der, Baldini G. Temporal cAMP signaling selectivity by natural and synthetic MC4R Agonists. Mol Endocrinol. (2015) 29:1619. doi: 10.1210/ME.2015-1071

140. Minokoshi Y, Alquier T, Furukawa N, Kim Y-B, Lee A, Xue B, et al. AMPkinase regulates food intake by responding to hormonal and nutrient signals in the hypothalamus. Nature. (2004) 428:569-74. doi: 10.1038/nature02440

141. Mountjoy KG, Kong PL, Taylor JA, Willard DH, Wilkison WO. Melanocortin receptor-mediated mobilization of intracellular free calcium in HEK293 cells. Physiol Genomics. (2001) 2001:11-9. doi: 10.1152/PHYSIOLGENOMICS.2001.5.1.11

142. Shen Y, Fu WY, Cheng EYL, Fu AKY, Ip NY. Melanocortin-4 receptor regulates hippocampal synaptic plasticity through a protein kinase A-dependent mechanism. J Neurosci. (2013) 33:464-72. doi: 10.1523/JNEUROSCI.3282-12.2013

143. Caruso V, Lagerström MC, Olszewski PK, Fredriksson R, Schiöth HB. Synaptic changes induced by melanocortin signalling. Nat Rev Neurosci. (2014) 15:98-110. doi: 10.1038/nrn3657

144. Newman E, Chai B, Zhang W, Li J, Ammori J, Mulholland M. Activation of the melanocortin-4 receptor mobilizes intracellular free calcium in immortalized hypothalamic neurons. J Surg Res. (2006) 132:2017. doi: $10.1016 /$ J.JSS.2006.02.003

145. Fu Y, Han J, Ishola T, Scerbo M, Adwanikar H, Ramsey C, et al. PKA and ERK, but not PKC, in the amygdala contribute to pain-related synaptic plasticity and behavior. Mol Pain. (2008) 4:26. doi: 10.1186/1744-8069-4-26

146. Carrasquillo Y, Gereau RW. Activation of the extracellular signal-regulated kinase in the amygdala modulates pain perception. J Neurosci. (2007) 27:1543-51. doi: 10.1523/JNEUROSCI.3536-06.2007

147. Haskell-Luevano C, Monck E. Agouti-related protein functions as an inverse agonist at a constitutively active brain melanocortin-4 receptor. Regul Pept. (2001) 99:1-7. doi: 10.1016/S0167-0115(01)00234-8

148. Breit A, Wolff K, Kalwa H, Jarry H, Büch T, Gudermann T. The natural inverse agonist agouti-related protein induces arrestin-mediated endocytosis of melanocortin-3 and-4 receptors *. J Biol Chem. (2006) 281:37447-56. doi: 10.1074/JBC.M605982200

149. Nijenhuis WAJ, Oosterom J, Adan RAH. AgRP(83-132) acts as an inverse agonist on the human-melanocortin-4 receptor. Mol Endocrinol. (2001) 15:164-71. doi: 10.1210/MEND.15.1.0578

150. Tolle V, Low MJ. In vivo evidence for inverse agonism of agouti-related peptide in the central nervous system of proopiomelanocortin-deficient mice. Diabetes. (2008) 57:86-94. doi: 10.2337/db07-0733

151. Yang $Z$, Tao Y. Biased signaling initiated by agouti-related peptide through human melanocortin-3 and -4 receptors. Biochim Biophys Acta. (2016) 1862:1485-94. doi: 10.1016/J.BBADIS.2016.05.008

152. Shinyama H, Masuzaki H, Fang H, Flier JS. Regulation of melanocortin4 receptor signaling: agonist-mediated desensitization and internalization. Endocrinology. (2003) 144:1301-14. doi: 10.1210/en.2002-220931

153. Cai M, Varga E V., Stankova M, Mayorov A, Perry JW, Yamamura HI, et al. Cell signaling and trafficking of human melanocortin receptors in real time using two-photon fluorescence and confocal laser microscopy: differentiation of agonists and antagonists. Chem Biol Drug Des. (2006) 68:183-93. doi: 10.1111/j.1747-0285.2006.00432.x

154. Ye DWI, Liu C, Liu TT, Tian XB, Xiang HB. Motor cortex-periaqueductal gray-spinal cord neuronal circuitry may involve in modulation of nociception: a virally mediated transsynaptic tracing study in spinally transected transgenic mouse model. PLoS ONE. (2014) 9:e89486.

155. Caruso C, Carniglia L, Durand D, Gonzalez P, Scimonelli T, Lasaga M. Melanocortin 4 receptor activation induces brain-derived neurotrophic factor expression in rat astrocytes through cyclic AMPprotein kinase A pathway. Mol Cell Endocrinol. (2012) 348:47-54. doi: 10.1016/J.MCE.2011.07.036

156. Carniglia L, Durand D, Caruso C, Lasaga M. Effect of NDP- $\alpha-$ MSH on PPAR- $\gamma$ and $-\beta$ expression and anti-inflammatory cytokine release in rat astrocytes and microglia. PLoS ONE. (2013) 8:e57313. doi: 10.1371/journal.pone.0057313 
157. Xu B, Goulding E, Zang K, Cepoi D, Cone R, Jones K, et al. Brainderived neurotrophic factor regulates energy balance downstream of melanocortin-4 receptor. Nat Neurosci. (2003) 6:736-42. doi: 10.1038/ NN1073

158. Glas E, Mückter H, Gudermann T, Breit A. Exchange factors directly activated by cAMP mediate melanocortin 4 receptor-induced gene expression. Sci Rep. (2016) 6:1-14. doi: 10.1038/srep32776

159. Uhl G, Liu Q, Walther D, Hess J, Naiman D. Polysubstance abusevulnerability genes: genome scans for association, using 1,004 subjects and 1,494 single-nucleotide polymorphisms. Am J Hum Genet. (2001) 69:1290300. doi: $10.1086 / 324467$

160. Palada V, Kaunisto M, Kalso E. Genetics and genomics in postoperative pain and analgesia. Curr Opin Anaesthesiol. (2018) 31:569-74. doi: $10.1097 / \mathrm{ACO} .0000000000000633$

161. Moonat S, Starkman BG, Sakharkar A, Pandey SC. Neuroscience of alcoholism: molecular and cellular mechanisms. Cell Mol Life Sci. (2009) 67:73-88. doi: 10.1007/S00018-009-0135-Y

162. Heberlein A, Muschler M, Wilhelm J, Frieling H, Lenz B, Gröschl M, et al. BDNF and GDNF serum levels in alcohol-dependent patients during withdrawal. Prog Neuropsychopharmacol Biol Psychiatry. (2010) 34:1060-4. doi: 10.1016/J.PNPBP.2010.05.025

163. Prakash A, Zhang H, Pandey SC. Innate differences in the expression of brain-derived neurotrophic factor in the regions within the extended amygdala between alcohol preferring and nonpreferring rats.
Alcohol Clin Exp Res. (2008) 32:909-20. doi: 10.1111/J.1530-0277.2008. 00650.X

164. Jeanblanc J, He D-Y, Carnicella S, Kharazia V, Janak PH, Ron D. Endogenous BDNF in the dorsolateral striatum gates alcohol drinking. J Neurosci. (2009) 29:13494. doi: 10.1523/JNEUROSCI.2243-09.2009

Conflict of Interest: The authors declare that the research was conducted in the absence of any commercial or financial relationships that could be construed as a potential conflict of interest.

Publisher's Note: All claims expressed in this article are solely those of the authors and do not necessarily represent those of their affiliated organizations, or those of the publisher, the editors and the reviewers. Any product that may be evaluated in this article, or claim that may be made by its manufacturer, is not guaranteed or endorsed by the publisher.

Copyright $\odot 2021$ Sharfman and Gilpin. This is an open-access article distributed under the terms of the Creative Commons Attribution License (CC BY). The use, distribution or reproduction in other forums is permitted, provided the original author(s) and the copyright owner(s) are credited and that the original publication in this journal is cited, in accordance with accepted academic practice. No use, distribution or reproduction is permitted which does not comply with these terms. 